\title{
THE ORPHANS, THE MARKET, AND THE COPYRIGHT DOGMA: A MODEST SOLUTION FOR A GRAND PROBLEM
}

\author{
Ariel Katr'
}

\section{TABLE OF CONTENTS}

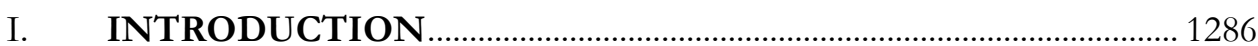

II. PERMISSION-FIRST: THE RULE ..................................................... 1288

III. PERMISSION-FIRST: THE DOGMA ……......................................... 1290

IV. COPYRIGHT LAW IS NOT THE COPYRIGHT DOGMA ............ 1293

A. SEARCH ENGINES AND TEChNOLOGICAL OPT-OUT ....................... 1294

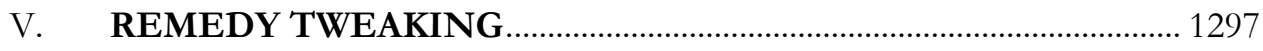

VI. JUSTIFYING REMEDY TWEAKING …………………………........ 1303

A. Why Do Works BeCome ORPHANS? ................................................ 1304

B. LEAST-COST AVOIDERS AND LEAST-COST ENABLERS...................... 1306

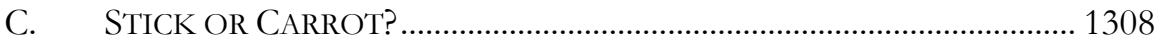

D. “Sit BACK, DO NOTHING” IS RARELY THE LAW............................. 1309

E. JUDICIAL AUTHORITY TO TWEAK REMEDIES..................................... 1314

VII. QUASI-DOGMATIC AND DOGMATIC SOLUTIONS..................... 1317
A. ThE U.S. COPYRIGHT OFFICE REMEDY TWEAKING
PROPOSAL
B. CANADA'S ORPHAN WORKS REGIME................................................. 1322
C. EXTENDED COLLECTIVE LICENSING ………………...................... 1331
D. DOES ECL EVEN SOLVE THE ORPHAN PROBLEM? .......................... 1335
E. ECL AS INSURANCE.............................................................................. 1336

(C) 2012 Ariel Katz.

† Associate Professor, Innovation Chair Electronic Commerce, Faculty of Law, University of Toronto. I wish to thank participants of the Berkeley Orphan Works Symposium ("Berkeley Symposium"), the 2012 Intellectual Property Scholars Conference, and the other events where earlier versions of this Article were presented, for their helpful feedback. I am also grateful to Tun-Jen Chiang, Robert Darnton, Natalie Zemon Davis, Abraham Drassinower, Ed Iacobucci, Lateef Mtima, Simon Stern, and Hal Varian for their insightful comments and suggestions, and to Pamela Samuelson for inviting me to participate in this symposium and her general support and encouragement. 


\section{THE POLITICAL ECONOMY OF THE COPYRIGHT} DOGMA

IX. CONCLUSION

1344

\section{INTRODUCTION}

How do you solve a problem like orphan works? The ability to digitize and make accessible through the internet works that are not commercially available has sparked the imagination of many. At the same time it has also directed the public's attention to the problem of access to and use of works that are still under copyright, but whose copyright owners are unlocatable. One of the most ambitious digitization projects, the Google Book Project, already generated a great deal of controversy and class action litigation, while a proposed settlement to that lawsuit turned out to be even more controversial and was ultimately rejected. ${ }^{1}$ The proposed settlement ${ }^{2}$ devised a solution to the orphan works problem, but raised antitrust, privacy, and international law concerns ${ }^{3}$ and implied, according to many, fundamental changes to copyright law's structure. ${ }^{4}$ With the rejection of the proposed settlement - and with Judge Chin's holding that only Congress is empowered to make such changes ${ }^{5}$ - many believe that a legislative change is necessary and that the orphan works problem is one which current copyright law, as implemented by courts, cannot solve. ${ }^{6}$ The thought is that the orphan works problem is grand, and, therefore, requires an equally grand solution.

In this Article, I warn against the quest for finding grand solutions. I analyze some of the proposed solutions and explain why most of them may do more harm than good. I also propose a common law solution to the orphan works problem, based on well-established principles of imposing and limiting liability from other areas of law. I show that courts can implement this solution, in large part, even if Congress takes no action.

Specifically, I propose to address the problem at the remedy stage, rather than by redefining liability. I propose that owners' locatability should be a

1. Authors Guild v. Google, Inc., 770 F. Supp. 2d 666 (S.D.N.Y. 2011).

2. See Amended Settlement Agreement (AS A), GoOGLE BOOK SETTLEMENT, available at http://www.googlebooksettlement.com/agreement.html (last visited Aug. 1, 2012).

3. See Authors Guild, 770 F. Supp. 2d at 682-86.

4. See, e.g., Pamela Samuelson, The Google Book Settlement as Copyright Reform, 2011 WISC. L. REV. 479 (2011).

5. Authors Guild, 770 F. Supp. 2d at 677-78 (stating that the issue of orphan works "is better left for Congress").

6. Pamela Samuelson, Legislative Alternatives to the Google Book Settlement, 34 CoLUM. J.L. \& ARTS 697, 698-700 (2011) (discussing the elements of a "legislative package" that could recreate the goals of the proposed settlement). 
mitigating factor that courts should consider when determining the proper remedy for the infringement of a copyright. In appropriate cases courts should deny injunctions and should also have some discretion to deny or reduce statutory damages. The court may still order the user to pay damages, or account for the profit attributable to the infringed work, but if these approximate what the parties would have agreed had a license been negotiated in advance, the orphan works problem would be seriously diminished. While many proposed solutions focus on mechanisms that exempt users of orphan works from liability (and thereby define circumstances and conditions that trigger an immunity), ${ }^{7}$ the proposed solution in this Article (which can be called "remedy tweaking" for convenience) focuses not only on the users' conduct but also on the owners' contribution to the problem. Therefore, this solution does not require any change in the basic rules that define when an infringement occurs but solves the problem by tailoring the ensuing remedy.

Remedy tweaking will shift some of the risk of using orphan works from the user to the owner. It will adjust the user's duty to seek ownership information and permission relative to a corresponding duty of the owner to provide such information. This should motivate copyright owners to make themselves locatable: to de-orphan their works. After all, the orphan works problem is a problem of those copyright owners' own making, and they are the ones who can mitigate it at the lowest cost. Tort law takes into account a plaintiff's contributory or comparative negligence; contract law demands that plaintiff take reasonable effort to mitigate their damage before they can recover its full extent. Property law sometimes imposes a duty to provide notice before a right can be enforced. The law does not recognize an unfettered right to sit back and do nothing in all circumstances and regardless of the consequences. Copyright law should not recognize such a right either.

I also discuss and warn against solutions that promote monopolies, such as those involving collective licensing or "extended collective licensing." The underlying assumption of this Article is that, at its core, copyright law is based on a very simple logic-market logic. Copyright law envisions a decentralized market system, whereby the law grants limited exclusive rights in creative works, with the expectation that such rights will then be voluntarily exchanged in a decentralized market place.

The idea of a decentralized marketplace lies at the heart of copyright law. Indeed, this idea was encoded in the DNA of copyright since its statutory

7. See discussion infra Part VII. 
inception. The Statute of Anne, the first copyright statute, arose not only out of the publishers' demands for statutorily protected exclusive rights, but also reflected the English Parliament's disdain of the monopoly that the Stationers' Company - the self-regulating cartel of London's publishers-had over the book trade. For nearly two centuries following arrival of the printing press in Britain, the London Stationers, alongside the Crown and the Cross, attempted to control the press and the book trade. ${ }^{8}$ The combination of monopoly and press control was an early reaction to the printing press by those who felt threatened by the ways it revolutionized how knowledge was being produced, disseminated, and controlled. ${ }^{9}$ At the turn of the eighteenth century, however, Parliament rejected such control, and modern copyright law was born. We should keep this point in mind when we design the rules governing the dissemination of knowledge as society moves from print to digital. And when facing specific problems, we should be cautious not to adopt solutions that could bring back a new version of the Stationers' Company and leave monopolies and bureaucracies as gatekeepers of orphan works and knowledge.

Part II explores the Permission-First Rule as the default rule in copyright law. Part III further discusses how the Permission-First Rule has become a dogma for copyright purists, and Part IV examines traditional deviations from the Permission-First dogma. Part V introduces "remedy tweaking" as a possible solution to the orphan works problem. Part VI continues with a discussion of how "remedy tweaking" is not only useful, but also justified. Part VII examines and critiques current "dogmatic" solutions to the orphan works problem. Part VIII discusses the political economy of the copyright dogma: who stands to benefit from promoting it, how the public stands to lose, and how those interests influence the proposed solutions. Part IX offers a brief conclusion.

\section{PERMISSION-FIRST: THE RULE}

As a general rule in copyright, a user ${ }^{10}$ should contact the owner and seek permission before using the work. Let us call it the permission-first rule. ${ }^{11}$

8. See, e.g., Joseph LoEWEnstein, The Author's DuE: Printing AND THE Prehistory OF COPYRIGHT 14 (2002); LyMAN RAY PATTERSON, COPYRight IN HistoricAl PERSPECTIVE 152-91 (1968).

9. See PATTERSON, supra note 8, at 152-91.

10. I use terms "user" and "use" for convenience, even though copyright law does not grant exclusive right to use a work, only exclusive rights with respect to specific uses such as reproduction and public performance. See 17 U.S.C. \$ 106 (2010).

11. Of course, "permission-first rule" is just a synonym for the now-standard term "property rule" (as distinct from a "liability rule") as used in the law and economics 
Generally in copyright, permission-first is a sensible rule-ordinarily it is much less costly for prospective users to ask permission from the owner, than for an owner to locate all actual or potential users and ask them to pay. ${ }^{12}$ In the paradigmatic case, the owner is singular, locatable, and stable, whereas users could be many and varied, scattered and fleeting. ${ }^{13}$ Moreover, requiring the putative user to approach the owner and seek permission forces the user to disclose the ways in which he plans to use the work; this, in turn, makes it easier for the owner to tailor the appropriate license fees and conditions through various forms of price discrimination. ${ }^{14}$ Therefore, a permission-first rule (and strict liability for violating it) generally supports copyright's market orientation.

But generally is not always, and not every case is paradigmatic. ${ }^{15} \mathrm{~A}$ permission-first rule only makes sense if the cost of getting prior permission is low, or at least low relative to the expected value of using the work, and if it is less costly for the user to seek prior permission than for the owner to

literature, following Calabresi \& Melamed. See Guido Calabresi \& Douglas Melamed, Property Rules, Liability Rules, and Inalienability: One View of the Cathedral, 85 HARV. L. REV. 1089 (1972). However, since the term "property" could have a broader meaning in law, outside law and economics, I prefer using "permission-first" in this paper to emphasize this particular aspect of the copyright entitlement.

12. See, e.g., Oren Bracha, Standing Copyright Law on Its Head - The Googlization of Everything and the Many Faces of Property, 85 TEX. L. REV. 1799, 1827 (2007); Antonio Nicita \& Giovanni B. Ramello, Property, Liability and Market Power: The Antitrust Side of Copyright, 3 REV. L. \& ECON. 767, 775 (2007).

13. The non-rivalrous nature of creative works exacerbates the problem because any user who has access to a work can practically use it without negotiating with the owner at all. Under a permission-later rule, some users would use without ever getting permission, hoping that their use would go unnoticed, and using any stalling tactic to delay payment once contacted.

14. See Wendy J. Gordon, Intellectual Property As Price Discrimination: Implications For Contract, 73 CHI-KENT L. REV. 1367, 1371-72 (1998).

15. While strict liability for copyright infringement has garnered wide support by courts and commentators, some commentators have offered more nuanced views and argued against its uniform applicability. See, e.g., Dane S. Ciolino \& Erin A. Donelon, Questioning Strict Liability in Copyright, 54 RutGers L. REV. 351 (2002); Avihay Dorfman \& Assaf Jacob, Copyright as Tort, 12 THEORETICAL INQ. L. 59, 77-82 (2011) (arguing that "the same considerations that call for the protection of tangible property through a regime of strict liability torts require (or may often require) abandoning this regime in the case of copyright" and replacing it with rules similar to those that apply to accidents, "which may include the owners' contributory or comparative negligence"); see also T. J. Chiang, The Reciprocity of Search, 66 VAND. L. REV. 1 (2013) (critiquing the way patent law, like copyright law, imposes the duty to locate patent owners solely on users). Chiang argues that, contrary to conventional wisdom, patentees are often better positioned to locate users and that the law should impose a duty to search on patentees in such cases. Id. Chiang also mentions the orphan work problem as a parallel problem in copyright law. Id. at 60-63. 
contact the user. ${ }^{16}$ If the cost of obtaining prior permission becomes prohibitively high relative to the contemplated use, then a system demanding prior permission would result in a market failure. The problem with many mass digitization projects-especially when they involve orphan, partly orphan, or quasi-orphan works ${ }^{17}$ - is that seeking permission first is either impossible or prohibitively costly. ${ }^{18}$ Therefore, in such cases permission-first is not a workable rule. In such cases we need an alternative rule. ${ }^{19}$

\section{PERMISSION-FIRST: THE DOGMA}

Unfortunately, solving the orphan works problem has been much more difficult than acknowledging its existence. One of the main obstacles has been a tendency to treat the permission-first rule as a dogma- " a belief held unquestioningly and with undefended certainty" validity should always be judged in light of the purpose of copyright law. For some copyright purists, the rule should be adhered to irrespective of circumstances and regardless of the consequences because "permission-first" is the essence of copyright, and anything else would turn copyright "on its

16. See Chiang, supra note 15.

17. A completely orphan work would be one where the owner is unknown and unlocatable. A work can be partly orphan if the owner is known but unlocatable (e.g., it is known that the author is John Smith and that he is American, but there are 45,352 Americans named John Smith, see HowMANYOFME, http://www.HowManyOfMe.com (last visited May 21, 2012)), or locatable but unknown (e.g., the work was written by an anonymous writer or under a pseudonym, although it would not be difficult to locate the author if only one knew her identity). By quasi-orphan work I mean a work in which ownership has changed without sufficient record, or a work with fragmented ownership which, practically, makes it prohibitively costly to negotiate a license.

18. The problem is by no means limited to digitization. As Eric Schwartz explained in his presentation at this symposium, the orphan state of many films is a challenge for efforts to preserve them, and presently, most preservation is done by non-digital means. Eric Schwartz, Panel Discussion, Orphan Works: Films and Recordings at the Berkeley Symposium: "Orphan Works and Mass Digitalization: Obstacles and Opportunities" (Apr. 12, 2012), available at http://www.law.berkeley.edu/11731.htm. Moreover, the orphan works problem is barely a new one. Indeed, the Ottoman Empire's copyright legislation from 1910 included a special rule applied to orphan works whose authors died and who had no heirs- the work could be copied, published and translated. See MiCHAEL D. BirnhaCK, Colonial Copyright: Intellectual Property in MANDATE PALESTine 85 (2012).

19. Fair use, which exempts the user from obtaining any permission, is sometimes explained as a rule designed to prevent such market failure. See, e.g., Campbell v. Acuff-Rose Music, Inc., 510 U.S. 569, 592 (1994) (reasoning that the "unlikelihood that creators of imaginative works will license critical reviews or lampoons of their own productions" justifies treating parodies as fair use).

20. Simon Blackburn, The Oxford Dictionary of Philosophy 104 (2d ed. 2005). 
head." 21 This view of copyright appears to have influenced Judge Chin in his decision to reject the proposed settlement in the Google case. ${ }^{22}$ Judge Chin endorsed a statement by Amazon's counsel, David Nimmer, that "[ $\mathrm{t}]$ he law of the United States is a copyright owner may sit back, do nothing and enjoy his property rights untrammeled by others exploiting his works without permission." 23 Sit back, do nothing, regardless of the consequences. The dogma.

For the copyright dogma, the wrong in using someone else's work without permission has nothing to do with impairing the ability of the copyright owner to participate in the marketplace or with depriving the owner of the opportunity to share the benefits resulting from the use of her work. Nor does it lie in any other measurable concept of harm to the owner or to society. If it did, there would be no problem recognizing that the permission-first rule could be relaxed when the owner is unlocatable or when the use cannot cause any harm and the rule prevents beneficial uses of the work.

The copyright dogma does not treat copying without permission as a harmful act against an owner but, rather, as a sinful act, wrongful in and of itself. The dogma does not regard the use of works as something that ought to be celebrated. It does not seek to justify copyright's limitations on use by the need to reward creators and encourage creativity, or to recognize authorial dignity. The dogma denies "that copyright law is less a prohibition on copying, or an obligation not to copy, than an institutionalized distinction

21. See Bracha, supra note 12, at 1802 (explaining the ideology of Google's critics that copyright owners should not "carry the burden" of enforcing their rights).

22. Authors Guild v. Google, Inc., 770 F. Supp. 2d 666, 669-70 (S.D.N.Y. 2011).

23. Id. at 681. Judge Chin viewed this conclusion as a natural corollary to the undisputed proposition that "[a] copyright owner's right to exclude others from using his property is fundamental.” Id. (citing Fox Film Corp. v. Doyal, 286 U.S. 123, 127 (1932)). But he did not provide any reference to the proposition that this fundamental right to exclude bears no exceptions whatsoever. In fact, if, as the Court held in Fox Film, the "primary object in conferring the monopoly lie[s] in the general benefits derived by the public from the labors of authors," then arguably, the ability to sit back and do nothing may be limited if it deprives the public from the very benefits that the copyright was designed to foster. See Fox Film, 286 U.S. at 127. In fairness to Judge Chin, however, the question he confronted was not whether there could be any circumstances justifying deviation from the permissionfirst rule, but whether to approve a highly controversial settlement that would involve a massive reshuffling of rights and the setting up of new institutions - a task which he thought would be better left for Congress. Authors Guild, 770 F. Supp. 2d at 677. Moreover, Judge Chin was not asked to consider (or reconsider) the dogma but, rather, to choose among competing interpretations of it. The lawsuit against Google, the Amended Settlement Agreement (ASA), and many of the objections to the ASA, were all reflections of the dogma. And like them, many proposed solutions to the orphan works problem are captive to it. 
between permissible and impermissible copying." 24 Therefore, in attempting to determine when the law should require prior permission the dogma does not use a matrix of considerations aiming to optimize reward, incentives, dissemination, freedom, dignity, or any such or other factors. The copyright dogma does not define copyright by the rights it confers on its owner and the correlative duties it imposes on others; it does not ask how those correlative rights and duties can be exercised and complied with in ways that promote the public interest, minimize interference with the rights and liberties and others, or otherwise achieve copyright law's purpose. ${ }^{25}$ Instead, it defines copyright solely by the prohibitions it imposes on users. Thus, the dogma views unauthorized copying as inherently sinful, and regards prior permission as the means to avoid and absolve that venial sin of copying.

When users and owners can easily obtain and grant permissions, debating the nature of the wrong in copyright may seem interesting but of little consequence. However, the question becomes crucial when transactions are prohibitively costly. Such situations pose an immediate challenge to the dogma. Obviously, if the copyright owner is unlocatable, there would be no mechanism to absolve the sin of copying. Therefore, to avoid sin, the dogma must insist that the work must never be copied. While this position may be internally consistent, it would not garner much political support if it sentences orphan works to oblivion. Consequently, to retain some of its appeal, the dogma must provide substitutions to the absent owner: someone else who can give permission (and collect a fee) in lieu of the absent owner.

The doctrinal move is less challenging than it initially appears. In fact, once the sin is detached from any concept of harm to the copyright owner and becomes the lack of permission itself, it no longer matters whether permission is sought from the owner or from someone else, as long as that person is willing to step into the shoes of the absent owner and collect a fee in her stead. In fact, one cannot help but suspect that those who could benefit from stepping into the shoes of the absent owners are those who have the greatest motivation to promote the dogma. ${ }^{26}$

This kind of development of the copyright dogma and the solutions that it proposes resemble some aspects of Catholic dogma in the Middle Ages; the Catholic Church realized that if it could not prevent sin altogether, it

24. See Abraham Drassinower, Copyright is Not About Copying, 125 HARV. L. REV. 108, 112 (2012).

25. See id. at 109-10; see also Shyamkrishna Balganesh, The Obligatory Structure of Copyright Law: Unbundling the Wrong of Copying, 125 HARV. L. REV. 1664 (2012).

26. See infra Part VIII. 
might as well monetize sin through the sale of indulgences. ${ }^{27}$ The similarities between the dogma's solutions and indulgences will be discussed later in the Article, infra. At this point, however, my purpose is to show that copyright law, unlike copyright dogma, is not very dogmatic at all. Indeed, deviations from the permission-first rule are part and parcel of copyright law.

\section{COPYRIGHT LAW IS NOT THE COPYRIGHT DOGMA}

Consider fair use and other exceptions to copyright. Fair use allows users, with some limitations, to copy protected works for legitimate purposes. ${ }^{28}$ Therefore, fair use "permits and requires courts to avoid rigid application of the copyright statute when, on occasion, it would stifle the very creativity which that law is designed to foster." 29 Creating an exception has sometimes been viewed as a solution that copyright law applies to situations in which requiring owners to get permission would result in a market failure. ${ }^{30}$ For example, it is very hard to imagine a functioning market for rights to criticize the works of others. ${ }^{31}$ This Article does not discuss fair use here to argue that fair use is the solution for the orphan works problem (although in some cases it certainly might be). ${ }^{32}$ Rather, the Article only mentions fair use to demonstrate that copyright law has departed from the permission-first rule when necessary. In fact, fair use goes beyond merely deviating from the permission-first rule because, when it applies, the user does not need to seek permission at all. ${ }^{33}$

27. Id.

28. 17 U.S.C. $\int 107$ (2010) (“[T] he fair use of a copyrighted work, including such use by reproduction in copies or phonorecords or by any other means specified by that section, for purposes such as criticism, comment, news reporting, teaching (including multiple copies for classroom use), scholarship, or research, is not an infringement of copyright.”).

29. Campbell v. Acuff-Rose Music, Inc., 510 U.S. 569, 577 (1994) (internal quotation marks and citation omitted).

30. See Wendy J. Gordon, Fair Use as Market Failure: A Structural and Economic Analysis of the Betamax Case and its Predecessors, 82 Colum L. REV. 1600, 1604-05 (1982).

31. See William M. Landes \& Richard A. Posner, The Economic Structure of INTELLECTUAL PROPERTY LAW 153 (2003); Campbell, 510 U.S. at 592 (explaining the distinction between "biting criticism that merely suppresses demand and copyright infringement, which usurps it") (internal quotations and punctuation omitted).

32. See Jennifer M. Urban, How Fair Use Can Help Solve the Orphan Works Problem, 27 Berkeley TeCH. L. J. 1379 (2012); see also William F. Patry \& Richard A. Posner, Fair Use and Statutory Reform in the Wake of Eldred, 92 CALIF. L. REV. 1639, 1639-61 (2004). The recent ruling in Authors Guild, Inc. v. HathiTrust, 11 CV 6351 HB, 2012 WL 4808939 (S.D.N.Y. Oct. 10,2012 ), may indeed indicate that fair use can be relied on to facilitate many digitization projects involving all works, including orphan works.

33. In fact, as others have noted, this feature of fair use is sometimes an issue because it can lead to extreme outcomes: strict liability if a defendant's fair use is rejected or zero 
There are, however, situations in which a duty to seek permission first (ex ante) might lead to a market failure_or a highly inefficient market_even though there might be room for negotiation ex post. In such cases, the law may not necessarily provide total exemption in the way that fair use does, ${ }^{34}$ but it may change the default rule. The law may shield a user from liability for using a work without getting prior permission until the copyright owner objects. The notice-and-take-down mechanism for online service providers ("OSPs") under $\int 512(\mathrm{c})$ of the Copyright $\mathrm{Act}^{35}$ is an example of such a mechanism. It creates certain limitations on the liability of OSPs for copyright infringement of their subscribers. The mechanism creates a safe harbor that allows OSPs to host the infringing material until the copyright owner provides notice of the unauthorized use. ${ }^{36}$ The notice-and-take-down mechanism does not endorse a "sit back, do nothing" approach. In fact, it conditions some of the copyright owners' entitlements on taking specific actions in prescribed form. ${ }^{37}$ Section $512(\mathrm{c})$ is but one example in which the law deviates from the "permission-first" rule. This particular rule immunizes OSPs from potential contributory or vicarious liability for the direct infringement of their subscribers. The next Section discusses an example of deviation from the "permission-first" rule that applies to direct infringers.

\section{A. SEARCh Engines and TeChNOLOgICAl Opt-Out}

The growing judicial endorsement of technological opt-out solutions, such as those applied by search engines, reflects another instance of courts' willingness to adopt solutions that deviate from a strict permission-first rule, but do not go as far as complete exemption. ${ }^{38}$

Consider the copyright issues that Google and other search engines face. In order to run its search engine, Google systematically copies every webpage on the Internet, stores it on its servers, and indexes it. And Google copies

liability if successful, without anything in between. See Alex Kozinski \& Christopher M. Newman, What's So Fair About Fair Use? The 1999 Donald C. Brace Memorial Lecture, 46 J. COPYRIGHT SOC’Y U.S.A. 513, 515 (1999) (“In fair use, as with pregnancy tests, 'a little bit' isn't considered an acceptable response. Fair use is conceptually a hard-edged box; either you're in it or you're out of it. If you're out, you can be enjoined out of existence.").

34. See 17 U.S.C. $\int 107$ (2010) ("[T] he fair use of a copyrighted work ... is not an infringement of copyright.”).

35. 17 U.S.C. S 512(c) (2010).

36. See id.

37. See Peter Dicola \& Matthew Sag, An Information-Gathering Approach to Copyright Policy, 34 CARdozo L. REV. 173, 183 (2012) (explaining the pervasiveness of "tolerated use" in social media contexts because copyright owners must provide a notice of alleged infringement).

38. See, e.g., Field v. Google Inc., 412 F. Supp. 2d 1106 (D. Nev. 2006); Parker v. Yahoo!, Inc., No. 07-2757, 2008 WL 4410095 (E.D. Pa. 2008). 
every such webpage without asking permission first. Obviously, Google could not personally contact every website owner and get her permission before indexing her website in a manner that was not extremely costly and inefficient. $^{39}$

Instead, Google believes that it can use an opt-out system. Google employs "Googlebot," a computer program, which, by default, copies every webpage and extracts from it the necessary data. ${ }^{40}$ Google does not seek permission first, but it does not copy and index a webpage against the website owner's wishes. ${ }^{41}$ To prevent unauthorized use, Google (and other search engines) rely on a technological opt-out system. This opt-out system allows website owners to automatically notify Google if they do not want their website or specific parts of it to be indexed. ${ }^{42}$ Website developers can simply insert widely available lines into the html code of the website (known as "Robots exclusion protocol" or robots.txt). ${ }^{43}$ Google's computers that otherwise would automatically copy everything recognize the code and know to keep out. ${ }^{44}$ Therefore, Google's business model relies on the theory that since strict compliance with a permission-first rule would be extremely inefficient, and since website owners are able to communicate their desires in a very simple, cheap, and effective way, it does not need to get permission first.

The legality of Google's theory has not been fully tested or universally accepted, and has on occasion been contested. ${ }^{45}$ With some exceptions, ${ }^{46}$

39. See Bracha, supra note 12 , at 1827 . Note, however, that it is not strictly impossible for Google to do that. In theory, Google could employ some people to visit websites, find their owner's contact details, and contact them to seek their permission to index them, but obviously this would be extremely inefficient.

40. Googlebot Webmaster Tools Help, GOOGLE, http://support.google.com/webmasters/ bin/answer.py?hl=en\&answer=182072 (last visited Apr. 20, 2012).

41. See Bracha, supra note 12, at 1827.

42. Id.

43. See About / robots.txt, ROBOTSTXT.ORG, http://www.robotstxt.org/robotstxt.html (explaining the robots exclusion protocol) (last visited Nov. 30, 2012).

44. Id.

45. See Google, Inc. v. Copiepresse, Cours d'Appel [CA] (Court of Appeal) Bruxelles, 9e ch. May 9, 2011, (Belg.), available at http://www.copiepresse.be/pdf/Copiepresse\%20\%20ruling\%20appeal\%20Google_5May2011.pdf (rejecting Google's argument that a failure to implement robots.txt protocols constituted permission to copy and index newspaper). The court reasoned that "it cannot be permitted that a holder is deprived of his rights simply because he has neglected to implement a technological process or, as [one of the respondents] so colorfully puts it, that it would be 'legal to rob a house of its contents because a door was left open!' " Id. $₫ 50$.

46. See id. 
courts have tended to be sympathetic towards this theory. ${ }^{47}$ However, it is important to note that this solution departs from the permission-first rule. It requires website owners to take concrete steps to signal the lack of permission. Essentially, this solution not only allows Google to say "we will copy you, unless you tell us not to," but it also allows Google to add "and unless you tell us not to in a very specific way." If the theory is upheld-and considering how rejecting it would thwart the utility of search engines one can hope that it will-it can teach an important lesson: when a permissionfirst rule is highly inefficient, an alternative system that imposes a minimal burden on copyright owners, while remaining responsive to and respective of their wishes, might be acceptable. The jurisdictions that endorse Google's practice for indexing websites clearly reject the notion that website owners, when they have copyright in the content of their website, can "sit back, do nothing" and have their website untouched. If they do not want Google to index their websites, they need to take action, and until they do, they will not have recourse against Google. ${ }^{48}$

Obviously, the technological opt-out solution that works for internet websites is not directly applicable to books that were not born digital; it also may not be available to many other mass-digitization projects and other uses of orphan and non-orphan works. Unlike websites, the "code" of printed books cannot contain robots.txt. But a general principle can be distilled from the technological opt-out mechanism that can apply more broadly, from forgotten orphans to living websites: when a permission-first rule leads to a market failure, or results in marked inefficiency, the law may deviate from permission-first. Further, if there is an alternative to the permission-first rule that, by imposing a minimal burden on owners, while remaining responsive to and respective of their wishes, prevents the market failure or avoids such inefficiency, the law should endorse such a rule.

47. See, e.g., Field v. Google Inc., 412 F. Supp. 2d 1106, 1109 (D. Nev. 2006) (granting Google's motion for summary judgment); see also Arnd Haller, German Supreme Court: Google Image Search in Line with Copyright Law, EUR. PUB. POL'Y BLOG (Apr. 11, 2012, 10:53 AM), http://googlepolicyeurope.blogspot.com/2012/04/german-supreme-court-google-image.html (discussing a decision by the German Supreme Court, which upheld the legality of Google's indexing methodology).

48. The implied assumption here is that Google has to be responsive to copyright owners' wishes when it copies their websites for the purpose of indexing them. There is, however, a credible argument that this kind of copying for non-expressive purposes does not infringe copyright at all. See Matthew Sag, Orphan Works as Grist for the Data Mill, 27 BERKELEY TECH. L.J. 1503 (2012). The implication of this view is that as a matter of copyright law, copying websites in order to index their content is a form of non-expressive use that ought to be allowed even against the wishes of copyright owners. 
In the context of search engines, this principle manifests itself in the form of a technological opt-out solution. But legally, and abstracting from the technological particulars of the solution, the principle can translate into a more general recognition that while users have a duty to seek permission before using - and not to engage in protected uses of the work against the owner's wishes-owners may have a corresponding duty to take reasonable steps to facilitate users' ability to seek permission or otherwise communicate their wishes efficiently. While failure to fulfill the user's duty would constitute an infringement of the copyright, failure to comply with the owner's duty might deprive her from some of the remedies to which she otherwise would be entitled.

\section{REMEDY TWEAKING}

The previous Part discussed some contexts where the copyright owner's right or her entitlement to the full range of remedies might be conditioned on communicating her wishes to users effectively. From that discussion emerged a broader and more general principle: while a user has a duty to refrain from engaging in protected uses of a work against its owner's wishes, the owner has a corresponding duty to take some steps to facilitate the user's ability to seek permission or otherwise communicate their wishes efficiently. A user who breaches his duty is an infringer, but an owner who fails to fulfill her part may be barred from certain types of relief. This Part applies the principle of owner responsibility to orphan works, and shows that the principle, as applied, provides a satisfactory solution to the problem of orphan works. Moreover, the discussion in this Part indicates that for the most part, this solution is within grasp. It requires neither "Grand Solutions," as followers of the dogma propose, nor substantial legislative reform. I call this solution "remedy tweaking."

The proposal is simple. The orphan works problem can be addressed by tweaking the remedies available for infringement. The locatability of the owner-the ease or difficulty of locating the owner-should be a factor that the court would consider when exercising its discretion in tailoring an appropriate remedy. This solution is similar in some respects to the proposal made by the Copyright Office in $2006^{49}$ but different in others. ${ }^{50}$ Rather than changing what constitutes an infringement, the problem of orphan works can be addressed by modifying the consequences arising from infringement.

49. REgister of COPYRIGHTS, REPORT ON ORPHAN WORKS (2006), available at http://www.copyright.gov/orphan/orphan-report-full.pdf.

50. See infra Section VII.A. 
Remedy tweaking will shift some of the risk of using orphan works from the user to the owner. It will adjust the user's duty to seek ownership information and permission relative to the owner's corresponding duty to provide such information. This solution will achieve two goals. First, it will remove some impediments to using the remaining orphan works because it will reduce the risk of disproportionate penalties. Second, it may shrink the number of orphan works by motivating copyright owners to make themselves locatable and "de-orphan" their works, and making it easier for users to seek permissions and obtain them.

The proposed solution does not change any of the basic rules of liability. Therefore, anyone who violates the owner's exclusive right is an infringer, ${ }^{51}$ regardless of whether the owner was locatable. Instead, the proposed solution takes into account the copier's ability to locate the owner and seek prior permission when the court considers the appropriate relief that the owner will be granted. When a defendant uses the work without permission and under circumstances where consent could have been easily obtained, the copyright owner should be entitled to the full range of remedies. However, when permission could not have been easily sought, the court may adjust the remedy. Thus, a court's inquiry should not be limited to asking "did the user seek permission before copying?", but should also include questions such as: "did the user made a good faith attempt to seek permission?", "what steps were taken?", and "what steps could have been taken but were not?". However, even if the court finds that the defendant could have taken additional measures that would have resulted in locating the owner, the court should also consider whether those measure should have been taken and whether they should have been taken prior to using the work or, perhaps, after. $^{52}$ In other words, what kinds of measures would be considered "reasonable" in the particular case? In this regard, the proposal is not limited to orphan works or to situations where the owner is unlocatable, but can apply to a wider range of situations, such as when locating the owner in advance is technically possible, but extremely inefficient. ${ }^{53}$

51. See 17 U.S.C. $\int 501(a)(2010)$.

52. Stef Van Gompel, Panel Discussion, The Orphan Works Chimera and How to Defeat It: A View from Across the Atlantic at the Berkeley Symposium: "Orphan Works and Mass Digitalization: Obstacles and Opportunities" (Apr. 12, 2012), available at http://www.law.berkeley.edu/11731.htm. In his presentation, Stef Van Gompel described how TV producers in the Netherlands sometimes add a notice at the end of the program announcing that they have tried to clear all necessary copyrights and invite anyone who believes that his work was used without permission to contact the producer.

53. As in the case of search engines, see supra Section IV.A. 
The answers to those questions may depend on different factors, such as the characteristics of the user, the nature of his project, the kind of work he copied, the availability of effective search tools and technologies, and so on. What may be reasonable in one case may not be reasonable in another. In addition, the court's inquiry should not only focus on the user's efforts to seek permission but also on the owner's efforts: what measures he took, could have taken, and should have taken to make it easy for prospective users to seek permission. The answers to these questions should also depend on various factors, such as the characteristics of the owner, the type of work, the tools and technologies that were available for recording and communicating ownership information to potential or actual users, and so on.

For example, a Hollywood studio producing a commercial film based on an orphan novel should be expected to exert more effort in locating the owner than a film student producing a film based on the novel. Or a producer of a commercial feature film should be expected to exert more effort than a producer of a low-budget documentary. If the name of the author or the publisher appear on the novel, the copyright was registered, and consulting the registry would easily lead to the current owner, then the differences between the productions and the producers might have little effect on the owner's entitlement to the ordinary range of remedies. But if the work in question is an old reprint of a photograph that plays a minor role in the film and bears no information whatsoever about the identity of the photographer or the copyright owner, then a limitation on the remedy might be equally appropriate whether the user is a Hollywood studio or a student. Yet, if the photo is new, and technologies exist that allow embedding ownership information in the photo itself (or embed an identifier that can be expeditiously matched against an accessible and reliable ownership database), ${ }^{54}$ then failure to contact the owner should weigh heavily against the user, while failure to embed this information should weigh against the owner.

Another consideration affecting the choice of remedy should be the timing of the lawsuit-whether action was brought before the work has been embedded in another project or after, and whether it can be easily taken out or replaced. Courts should consider these factors in determining whether granting an injunction would give the owner disproportionate leverage that would allow her to demand a settlement payment that far exceeds what would have been negotiated ex ante. ${ }^{55}$ Therefore, when an injunction would

54. See Molly Shaffer Van Houweling, Author Autonomy and Atomism in Copyright Law, 96 VA. L. REV. 549, 557-58, 631-32 (2010).

55. See Chiang, supra note 15 , at 7-8 (describing the similar holdup problem in the context of patents). 
give the owner a disproportionate holdup power, the court may deny an injunction, and limit the remedy to an award of damages. ${ }^{56}$ That courts are permitted to deny injunctive relief is currently beyond dispute. ${ }^{57}$

The possibility of injunctive relief may be a serious deterrent for some users contemplating the use of an orphan work, especially if the work cannot be taken out or replaced (e.g., a movie based on an orphan novel). But if the court only awards damages approximating what the parties would have agreed to had a license been negotiated in advance, the orphan works problem would be seriously diminished. As the Article discusses in more detail, infra, most orphan works are presumably those with very low expected commercial value; they presumably are not the ones that would have allowed the owner to bargain for any significant license fees ex ante. For some uses, there would be many close substitutes to any single orphan work, meaning that any license fees negotiated ex ante would be close to zero, ${ }^{58}$ although this may not be the case in all types of uses. For example, users engaged in non-fictional projects may wish to incorporate specific works to which no other work may be a substitute, whereas projects such as digital archives, indexes, or libraries may wish to include as many works as possible. The value of such products often increases the more comprehensive they are,

56. In fact, as Hal Varian explains, copyright owners' holdup power may lead users to refrain from seeking permission and using works even when the owners are locatable. Hal R. Varian, Copyright Term Extension and Orphan Works, 15 INDus. \& CORP. CHANGE 965, 972 (2006), available at http://icc.oxfordjournals.org/content/15/6/965.full.pdf. That is because the "effort exerted by the buyer is a sunk cost; there is no reason for the seller to take it into account in setting a price. But the result is that the buyer can never recover its costs of search, leading it to avoid even trying." Id. This is another reason why remedy tweaking may be an approach that should be used more broadly, not only for works that are designated as orphaned.

57. See eBay Inc. v. MercExchange, L.L.C., 547 U.S. 388, 392-93 (2006) ("Like the Patent Act, the Copyright Act provides that courts 'may' grant injunctive relief 'on such terms as it may deem reasonable to prevent or restrain infringement of a copyright.' And as in our decision today, this Court has consistently rejected invitations to replace traditional equitable considerations with a rule that an injunction automatically follows a determination that a copyright has been infringed.") (internal citations omitted).

58. Cf. Ty Inc. v. Perryman, 306 F.3d 509, 512 (7th Cir. 2002) (explaining the concept of "free riding" in the trademark context). Judge Posner remarks that it is unlikely that the owner of a prestigious trademark could obtain substantial license fees where there is no consumer confusion or brand tarnishment because competition would drive the fee to zero; if the name is being used in an unrelated market, virtually every prestigious name would be a substitute for every other in that market. $I d$. In the copyright context, consider, for example, a movie scene in which a protagonist is sifting through old family photographs - obviously, there could be numerous photographs that could be equally suitable for inclusion, not to mention the ability to digitally produce old-looking photograph with Photoshop or similar computer programs. 
meaning that the individual works are complements and not mere substitutes. ${ }^{59}$ In any event, the fact that the owner has let the work become orphaned should be viewed as a concession that she did not expect to be able to command any significant license fees.

An infringement of copyright may normally entitle the owner to receive the profit accrued to the user and attributable to the infringed work. ${ }^{60}$ The risk (and the resulting potential for over-deterrence) that accounting for profit may pose depends on the nature of the user's project. For example, projects such as libraries, archives, or indexes may be highly valuable (and profitable-think Google), but the value (and profit) that can be attributable to any single work may be quite small. Subject to the risk of statutory damages and class actions, which will be addressed below, the risk of accounting for profit may not be a significant deterrent for pursuing these projects. In other types of projects, such as recorded songs, movies, or other derivative works, the profit attributable to the infringed work might be quite high (or viewed as such to a judge or jury). In such cases, using an orphan work might be risky. Limiting the amounts that the copyright owner may recover will reduce the risk. ${ }^{61}$

Moreover, although in some cases denying an injunction and opting for a tweaked monetary award may reduce the risk associated with using orphan works, in other cases-especially those involving non-commercial activities-injunctive relief might be more appropriate than a monetary remedy. The purpose of this Article is to propose remedy tweaking in broad brush, not to work out its specific details; the idiosyncrasies of the many users, uses, works, and owners suggest that working out the optimal solution requires a case-by-case analysis better left to the courts.

The crucial point is that remedy tweaking will shift some of the risk of using orphan works from the user to the owner. This, in turn, will motivate copyright owners to make themselves locatable-to de-orphan their works-

59. Whether this complementarity would allow the owner to exercise any market power depends on how much withdrawing the work might decrease the project's total value. Even if no individual work may allow the owner to hold up the project completely, even a small amount of fees per work may accumulate to a significant amount that exceeds the user's ability to pay. This might be a justification for the favorable treatment of libraries and archives under copyright law, or broad fair use rights for such projects, although this exceeds the scope of this Article.

60. See 17 U.S.C. \504(b) (2010) ("The copyright owner is entitled to recover the actual damages suffered by him or her as a result of the infringement, and any profits of the infringer that are attributable to the infringement.").

61. Section VI.D, infra, discusses whether courts have the power to tweak such remedies. 
and encourage users to revive orphan works when their owners are still unlocatable. Since courts have wide discretion to tailor the right remedy for the individual case, they can tweak the remedies when appropriate even if Congress takes no legislative action on the issue of orphan works. Of course, Congress can adopt legislation that encourages courts to exercise this discretion, or simply clarifies that such discretion exists. But with two possible exceptions, remedy tweaking, unlike other proposed solutions, does not depend on statutory reform.

One exception is statutory damages. If courts indeed do not have discretion to deny or reduce them below the statutory minimum, statutory damages may remain a significant problem. ${ }^{62}$ Without such flexibility the remedy may not be fully tweakable. Therefore, statutory reform that ensures judicial discretion would be fruitful. ${ }^{63}$

The other exception is class actions. Remedy tweaking may work well when users contemplate using one or just a few works (or more accurately, when the use involves one or just a few claims of infringement). In such

62. As others have noted, the award of statutory damages - that can fairly be deemed "grossly excessive" - may violate due process of law. See J. Cam Barker, Grossly Excessive Penalties in the Battle Against Illegal File-Sharing: The Troubling Effects of Aggregating Minimum Statutory Damages for Copyright Infringement, 83 TEx. L. REV. 525, 538-40 (2004) (discussing the history of the Supreme Court's approach to excessive punitive damages); see also Pamela Samuelson \& Tara Wheatland, Statutory Damages in Copyright Law: A Remedy in Need of Reform, 51 WM. \& MARY L. REV. 439, 480-91 (2009) (discussing numerous cases in which the damage awards seem inconsistent with legislative intent).

63. See Barker, supra note 62, at 558 (advocating for statutory reform to create more "nuanced apportionment" of damages); Samuelson \& Wheatland, supra note 62, at 509-10 (arguing for reforms that grant courts the ability to reduce statutory damages in certain contexts and limit the availability of statutory damage awards, overall). Although this point does not seem to have been raised in the American literature on statutory damages in copyright law, it is arguable that, at least in some common law jurisdictions, courts possess an inherent power to grant relief against penalties and forfeitures and deny an award that is grossly disproportionate to the plaintiff's harm and to the defendant's blame. For example, Section 98 of the Ontario Courts of Justice Act, provides that "[a] court may grant relief against penalties and forfeitures, on such terms as to compensation or otherwise as are considered just." Courts of Justice Act, R.S.O. 1990, c. C.43, s. 98 (Can.), available at http://canlii.ca/t/ldxl. The Supreme Court of Canada explained that " $[\mathrm{t}]$ he power to grant relief against forfeiture is an equitable remedy and is purely discretionary. The factors to be considered by the Court in the exercise of its discretion are the conduct of the applicant, the gravity of the breaches, and the disparity between the value of the property forfeited and the damage caused by the breach." See Saskatchewan River Bungalows Ltd. v. Maritime Life Assurance Co., [1994] 2 S.C.R. 490 (Can.), available at http://canlii.ca/t/1frs7 (last visited Sept. 24, 2012). See also Jones v. New York Guaranty \& Indemnity Co., 101 U.S. 622, 628 (1879) ("A court of equity abhors forfeitures, and will not lend its aid to enforce them. Nor will it give its aid in the assertion of a mere legal right contrary to the clear equity and justice of the case.") (internal citations omitted). 
cases, tweaking the remedies encourages wider use of orphan works (by reducing the user's risk), and will also narrow the scope of the problem by encouraging owners to make themselves locatable. However, in projects that involve a large number of potential claimants, such as mass digitization projects, the aggregation of many small claims through a class action may still pose a significant risk of excessive damage awards. ${ }^{64}$ Statutory reform to eliminate, or at least reduce, the threat of a class action filed on behalf of owners of orphan works might seem desirable as well.

It is possible, however, that accepting the rationale that justifies remedy tweaking may also reduce the risk of class action suits without any need for statutory reform: recognizing the relevance of the owner's locatability may prevent a court from certifying a class that indiscriminately includes owners of orphan works with owners of non-orphans. Moreover, if the behavior of the owner, and not only that of the user, becomes part of the calculus, then it might not even be possible to certify two subclasses (non-orphans and orphans) because each of such subclasses may not exhibit a sufficient degree of commonality. It might be possible, in theory, to overcome this hurdle by defining a large number of sub-classes, but at some point, the case may simply not be suitable for a class action. And practically, even before reaching this point, such a case might be much less attractive for class action lawyers and plaintiffs, because the larger the number of subclasses, the higher the cost of litigating such a case, and the lower the expected payoff to the lawyer and the representative plaintiffs of each subclass.

\section{JUSTIFYING REMEDY TWEAKING}

Part V, supra, explained how remedy tweaking could provide a commonlaw solution to the orphan works problem by reducing the risk resulting from using such works, and encouraging owners who wish to be able to entitle to the full range of remedies, to take steps to prevent their works from becoming orphaned. This Part explains why this solution is not only useful but also justified. It begins by probing deeper into the orphan works problem, explains why remedy tweaking addresses the root causes of the problem, and proceeds to show how this solution is not a radical one, but in fact a common solution to similar and well known problems in various areas of the law, such as contract law, tort, and property.

64. See Samuelson \& Wheatland, supra note 62, at 490; see also Bracha, supra note 12, at 1828 (illustrating how large aggregate damage awards can get when each violation entails an award between $\$ 750$ and $\$ 30,000)$. 


\section{A. Why DO WORKS BECOME ORPHANS?}

Understanding the root causes of the orphan works problem is a useful step towards finding appropriate solutions. The problem tends to be described as a demand side problem: a problem of users who refrain from using works because they cannot locate the owners to seek permission and are deterred by the risk of liability. But focusing on the demand side and ignoring the supply side neglects that the orphan works problem is one of copyright owners' own making. This neglect limits our understanding of the problem and, therefore, tends to lead to proposed solutions that are equally focused on the demand side and ignore solutions that take into account the owners' part in creating the problem. ${ }^{65}$

Shifting attention to the supply side raises an immediate puzzle. If there is demand for reusing orphan works, then one could expect that rational owners would have an incentive to make themselves easily locatable. After all, when there is demand, the forgone uses are lost opportunities for copyright owners, not only for users and the public. ${ }^{66}$ This could suggest that the orphan works problem is not a serious one, or that the problem is not one that we-as society_-should be concerned about. Arguably, if works are not used because it is too costly to locate the owner, using them is actually inefficient because the cost outweighs the benefits. The relevant cost is not only the marginal cost of reproduction (which the user is willing to incur) but also the transaction costs that a society that has chosen to have a copyright system must be willing to accept.

Furthermore, it can be expected that digitization and the Internet will probably continue to create new ways to exploit works, while also reducing some of the costs of finding owners and communicating with them. The combination of higher demand and lower transaction cost will inevitably cause the orphan work problem to shrink. In other words, it is possible that the brunt of the orphan works problem is felt only because the speed with which digitization and the Internet have created new demand has not yet been met with an equally speedy supply, but it will. The problem, accordingly, might be seen as a temporary one, and the policy implication is that we only need some patience, not reform.

While there may be some merit to this point of view, it is only partly correct because the orphan work problem is not a temporary one-it is endemic to copyright. The orphan works problem runs deeper because it reflects discrepancies between the social benefits of using works and the

65. See infra Section VII.A.

66. Id. 
private benefits accruing to the owner, and between the social costs and private costs of forgone uses. ${ }^{67}$ This mismatch between public and private costs and benefits arises because a copyright owner has to incur some expenses in order to maintain herself locatable. Therefore, the owner will rationally incur those costs only if the present value of the benefits that she expects to gain is larger than the costs that she needs to incur. ${ }^{68}$

The owner, however, cannot expect to capture the full social benefit from the use of her work, only a portion of it. ${ }^{69}$ In addition, whatever license fees she might expect to earn in the future is discounted because the future is remote and unknown. ${ }^{70}$ Yet, the decision of how much to invest in maintaining herself locatable depends only on the ratio between the owner's private benefits and costs. Although the public benefits from future use, the public costs of forgone uses are not internalized by the owner. This mismatch between the expected social benefit and the expected private benefit to the owner leads owners to make socially sub-optimal investments in maintaining themselves locatable. In other words, owners do not internalize the full cost of their works becoming orphan, and the current system does not provide them enough incentive to invest in making themselves locatable. ${ }^{71}$

A similar problem exists on the user side. In many cases the social benefit of using the work exceeds the benefit to the user. This limits the amount of resources that the user is willing to spend in order to locate the owner and pay license fees to legally use the work. Under a strict permission-first rule,

67. See Varian, supra note 56, at 970-71 (recognizing the mismatch between the private costs and benefits for owners and users and the social optimum).

68. STEVEn SHAVELl, FOUNDATIONS OF ECONOMIC ANALYSIS OF LAW 87 (2004) (noting that bargaining may not occur when mutually beneficial agreements exist when the costs of bargaining-including the costs of coming together and the time and effort devoted to the bargaining process itself-outweigh the expected benefits).

69. Cf. Bracha, supra note 12, at 1838 (emphasizing that users cannot appropriate the full social value of their uses and therefore will abandon projects when the costs of getting permission are too high); see also Brett M. Frischmann \& Mark A. Lemley, Spillovers, 107 COLuM. L. REV. 257, 259-61 (2007) (defining the concept of "spillovers," or positive externalities, and explaining why owners of intellectual property never fully capture the full value of their creations).

70. The magnitude of this discount may vary among different owners. As Randy Picker notes, some owners might actually be overly optimistic about the prospects and value of future uses. Randal Picker, Panel Discussion, Private Digital Libraries and Orphan Works at the Berkeley Symposium: "Orphan Works and Mass Digitalization: Obstacles and Opportunities" (2012), available at http://www.law.berkeley.edu/11731.htm This phenomenon is also consistent with Sprigman and Buccafosco's "Creativity Effect." Christopher Sprigman \& Christopher Buccafosco, The Creativity Effect, 78 U. CHI. L. REV. 31 (2011).

71. Varian, supra note 56, at 971. 
using an orphan work becomes too risky and therefore too costly from the user's perspective, even when it is socially desirable to use it. Consequently, users may make socially sub-optimal investment in locating owners. ${ }^{72}$

\section{B. LEAST-COST AVOIDERS AND LEAST-COST ENABLERS}

Looking at the orphan works problem from both the demand and supply sides and restating it as a problem of costs (and benefits) that are not fully internalized by the relevant parties reveals that the orphan works problem is quite familiar. The problem ceases to be seen an idiosyncratic copyright anomaly and instead appears to reflect a common issue that exists throughout the law; and one that has familiar solutions. ${ }^{73}$

Restated as a problem of costs that are not fully internalized by the copyright owner or the user, we can approach a solution by invoking the concept of the least-cost avoider from the law and economics literature on tort law. Beginning with Coase's recognition that harm is often reciprocal in nature ${ }^{74}$ — caused by injurers as well as victims - the notion of the least-cost avoider supports the claim that the party who can avoid the harm at the lower cost should have a duty to take measures to avoid such harm. ${ }^{75}$ If the same logic is applied to the orphan works problem, the question becomes which of the parties is capable of avoiding the orphan works problem and the resulting forgone socially valuable uses at a lower cost. ${ }^{76}$ In the case of orphan works, the copyright owner is typically the least-cost avoider because she is the one who always knows who she is and where she can be found. ${ }^{77}$ Typically, no one else knows that better than her. ${ }^{78}$

The analogy to accidents and to the notion of the least-cost avoider is useful but incomplete. In the context of accidents, the concern is with avoiding harm that occurs in the course of involuntary relationships between injurers and victims who cannot reach a mutually beneficial agreement about

72. Id.

73. Id. at $971-72$.

74. See R. H. Coase, The Problem of Social Cost, 3 J.L. \& ECON. 1, 2 (1960).

75. See Guido Calabresi, The Costs of Accidents: A Legal and Economic ANALYSIS 135-40 (1970).

76. See Dorfman \& Jacob, supra note 15, at 94 ("[T] he breach of copyright should be assessed by reference to a more relaxed set of considerations familiar in the law of torts: who the cheapest cost avoider is; who has better information and better ability to prevent the harm; who is better able to carry the final burden; how to balance between the competing claims of the parties (to freedom, security, and so on).").

77. Bracha, supra note 12, at 1838-39.

78. Id. 
their respective activities. ${ }^{79}$ In contrast, in the copyright context we are concerned with designing legal rules that will enable voluntary transactions and their associated benefits whenever those transactions can maximize social utility. The problem is not how to deter harmful activities but how to encourage beneficial ones. Thus, the nature of the problem is the mirror image of the accident problem, and, therefore, instead of talking about leastcost avoiders, it may be more accurate to talk about least-cost enablers. This requires us to unpack the transaction and identify, with respect to each of its elements, the party that can enable it at a lower cost. It may take one party to avoid an accident, ${ }^{80}$ but for a voluntary licensing transaction to take place both a user and a copyright owner are necessary. Therefore, each party can take measures to facilitate the transaction, and optimal legal design would encourage each party to take those measures that she is better positioned to take and act where she is the least-cost enabler. For a transaction to take place, the user must communicate his wishes to use the work- the user is the least-cost enabler of this element of the transaction. Copyright law recognizes that truth by requiring users to seek permission. But the user cannot communicate his wishes to an unlocatable owner, even though, as noted above, the owner is typically the one who always knows who she is and where she can be found. The owner is the least-cost enabler of this element of the transaction. Unfortunately, the law is not always as cognizant about this point.

However, if the copyright owner is the least-cost enabler of her part of the transaction (or the least-cost avoider of the orphan works problem) but does not have good incentives to maintain ownership information available, the law can create these incentives with sticks, carrots, or both.

One type of carrot could be to increase the owner's expected benefits by increasing the term of copyright protection, but this solution is unlikely to be effective because copyright term is already so long; the present value of any additional profit resulting from longer terms is virtually zero. ${ }^{81}$ Moreover,

79. If there were no transaction costs, injurers and victims could reach agreements maximizing the joint value of their activities without legal intervention. See Coase, supra note 74 .

80. See SHAVELL, supra note 68, at 189 ("The notion of the least-cost avoider applies in situations in which the risk of accidents will be eliminated if either injurers or victims take care. In such situations it is clearly wasteful for both injurers and victims to take care; rather, it is optimal for the type of parties who can prevent accidents at least cost- the least-cost avoiders-alone to take care.”) (emphasis in original).

81. See Varian, supra note 54, at 968. See also Brief for George A. Akerlof, et al. as Amicus Curiae Supporting Petitioners at 8, Eldred v Ashcroft, 537 U.S. 186 (No. 01-618), available at http://eon.law.harvard.edu/openlaw/eldredvashcroft/supct/amici/economists.pdf. 
since copyright entails social costs, this solution will likely be counterproductive. Indeed, the orphan works problem itself is partly a result of exceedingly long copyright terms and automatic protection. ${ }^{82}$ Another type of carrot could be to subsidize the cost of maintaining ownership information by creating publicly funded registries. The utility of this solution is limited because even when registries are available, in order to be effective, owners still need to have their works registered and later record any changes in ownership or in their contact details. Therefore, to be effective, the carrot of a publicly funded registry may need to be accompanied with some sort of stick in the form of a negative consequence for failure to register. ${ }^{83}$ The fact that the orphan works problem persists in countries that have federally funded copyright registries, such as the United States or Canada, illustrates this point. ${ }^{84}$

Given the limitations on using plain carrots as incentives to maintain ownership information, the incentive must come in the form of a stick. Remedy tweaking provides this kind of stick. This solution recognizes that the social cost of orphan works may be avoided, and the least-cost avoider is generally the copyright owner. Therefore, a copyright system that seeks to maximize the voluntary use of works would seek to make sure that owners have proper incentives to keep themselves locatable. Remedy tweaking recognizes that while the copyright owner's exclusive right entails a corresponding duty on non-owners to refrain from copying the work without permission, the copyright owner has a duty to make herself locatable.

\section{STICK OR CARROT?}

Even though remedy tweaking can be formulated as a stick ("if you don't make yourself easily locatable ex ante you will be entitled to less ex post”), it can also be formulated as a carrot ("you, the owner, can choose between investing today in order to keep yourself locatable in the future, in which case you will be entitled to all the remedies, OR you can choose to invest less today, but might earn less in the future"). Formulating remedy tweaking as a carrot is not merely a semantic point or a rhetorical device. In fact, relaxing the permission-first rule by recognizing a duty to be locatable does not necessarily harm copyright owners, and in fact may be beneficial to them. To see why, recall that the decision to orphan the work is based on the copyright

82. Varian, supra note 54, at 968-69; LAwrenCE LeSSIG, FreE Culture: How BIG Media Uses Technology and the Law to Lock Down Culture and Control CREATIVITY 135 (2004).

83. See Van Houweling, supra note 52.

84. See Bracha, supra note 11, at 1829 (noting the lack of sufficient incentive to register copyright). 
owner's calculation of the present value of future uses, which in turn, depends on the copyright owner's prediction of what the future might entail. ${ }^{85}$ But the owner's ability to predict who might wish to exploit her work in the future and for what purpose is inherently limited. In contrast, the future user who wants to use the work knows who she is, and may also have better information than the owner about the expected value of the use. ${ }^{86}$ Unfortunately, under a strict permission-first rule the owner's decision not to invest in keeping herself locatable may be rational, but is also partly irreversible, because strict liability might deter users from using it and thus sending the owner a signal that there might be renewed interest in the work. To prevent this from happening, some owners may actually over-invest in keeping themselves locatable. Remedy tweaking might therefore benefit owners because it encourages users to reuse the work, and thereby signal to owners that there is renewed interest in their works even if it has become orphaned. Rather than incurring the full cost of maintaining themselves locatable, a relaxed rule allows the owner to economize on the information that users provide by using.

While remedy tweaking may reduce the owner's bargaining power vis-àvis the user, this may be a small price to pay because it reduces over deterrence and opens up new opportunities for compensable transaction. The alternative-under a strict permission-first rule-can make both the owner and the user worse off. In any event, an owner who wishes to retain a greater bargaining power can do that by maintaining herself locatable. ${ }^{87}$ Therefore, remedy tweaking allows both owners and users to choose between different strategies with respect to managing opportunities and risks.

\section{D. “Sit Back, Do Nothing” is Rarely the LaW}

As discussed in Part III, supra, Judge Chin's statement that copyright law allows owners to sit back and do nothing does not fully reflect current copyright law. Moreover, if understood to be more than merely a description of an entitlement protected by a property rule, rather than a starting point for the study of the instances in which the law may deviate from it, the statement is inconsistent with the law more broadly. If the statement stands for the proposition that a copyright owner may sit back, do nothing, regardless of the circumstances and regardless of any consequences, this would be a rare occurrence within our legal system. As the following examples illustrate, the law rarely recognizes such an unfettered right to sit back and do nothing, and

85. See supra text accompanying note 70 .

86. See supra text accompanying note 12 .

87. See supra Part I. 
frequently demands or encourages right holders to take action to minimize negative consequences arising from their inaction.

This Article has already alluded to tort law and the concept of the leastcost avoider, ${ }^{8}$ but tort law can teach more than that. While tort law may protect victims' rights over their bodies or property, it protects those entitlements under two distinct regimes, which can be roughly described as a non-accident regime and an accident regime, the differences between which are relevant to the current discussion. As Dorfman and Jacob note:

The "non-accident" regime, as generally manifested in the intentional torts and their strict liability approach, carries with it a "package" ensuring that the wrongdoer will seek the consent of the right-holder and, thus, engage the latter in a market interaction. If one does not seek permission prior to entrance-she will not only have to pay for the actual damage, but also be exposed to criminal liability, punitive damages, disgorgement of profits, etc. The accident regime, on the other hand, assumes that market transaction is not a viable option (whatever the reason may be). At the same time, it aims to promote productive activities, at least to a certain extent. Therefore, the accident regime will allow actors to inflict damage on others: Negligence law would only require them to act in a reasonable manner, while absolute liability would impose on them the entire risk of the materialized accident, regardless of reasonable care being taken. ${ }^{89}$

When tort law protects the owner of a right under an accident regime, rarely will it permit the owner to sit back and do nothing if it would be reasonable to take action to minimize risk and maximize social utility. That is, strict liability rules, completely disregarding the victim's behavior, are a rarity. As Shavell notes, "strict liability does not lead to the socially optimal outcome for the obvious reason that it fails to furnish victims a motive to take care. ${ }^{, 90}$ Even when the law adopts a standard of strict liability, the victim's behavior may be relevant, either by recognizing a defense of contributory negligence or by looking at the parties' comparative negligence. ${ }^{91}$ Moreover, even under the non-accident regime-as in the case of intentional torts, where invasions to one's tangible property are actionable as trespass and impose strict liability on the tortfeasor-the choice of this particular form of liability is "not a logical feature of ownership or private property ... [but] to an important extent a feature of certain facts about the

88. See supra Section VI.B.

89. Dorfman \& Jacob, supra note 15 , at 83.

90. SHAVELL, supra note 68 , at 188.

91. Id. 
world occupied by owners and non-owners of material objects." 92 Strict liability for intentional torts is justified because those torts "involve not a conflict between legitimate (productive) activities but a coerced transfer of wealth to the defendant in a setting of low transaction cost." ${ }^{.93}$ Therefore, "[s]o long as there is a market, the law will null all incentives to bypass it."," Yet the very considerations that justify strict liability when market transactions are available warrant a switch to an accident-like regime where the injurer's activity, while socially productive, may inflict harm on another, yet the costs of transacting are prohibitively high. ${ }^{95}$ In such cases, "tort law will provide ... 'guidelines' about how to act with due care. In doing so, courts and legislators take into account not only the interest of the injurer and the injured party ... but also society's, attempting to maximize the overall welfare." 96

Furthermore, tort law encourages action not only in order to minimize the occurrence of accidents, but also to minimize harm arising from accidents that do occur. Thus, injured victims who fail to take reasonable steps to minimize their harm after accidents occur, for example by seeking post-injury medical treatment, may not be entitled to compensation for their full damages. In reaching this conclusion, the Supreme Court of Canada reasoned that this " 'duty to mitigate' derives from the general proposition that a plaintiff cannot recover from the defendant damages which he himself could have avoided by the taking of reasonable steps."97

92. See Dorfman \& Jacob, supra note 15 , at 79.

93. Id. at 85 (quoting Richard A. PoSNER, ECONOMIC ANALYSIS OF LAW 205 (1999)).

94. Id.

95. See id.

96. Id. at 86. Dorfman and Jacob describe several features of copyright, which, according to them, justify greater reliance of accident-like rules of liability. They claim that knowing the identity of the owner of tangible property is typically easier than ascertaining the owner of a copyright, and they use orphan works as an example: "We all know the term 'orphan work,' but in tangible property this term is not yet to be coined. The term 'orphan house' has an entirely different meaning." Id. at 92.

97. Janiak v. Ippolito, [1985] 1 S.C.R. 146, 36 (Can.); see also RESTATEMENT (SECOND) OF TORTS \918 (1965). Section 918 of the Restatement (Second) of Torts provides for the following:

(1) Except as stated in Subsection (2), one injured by the tort of another is not entitled to recover damages for any harm that he could have avoided by the use of reasonable effort or expenditure after the commission of the tort. (2) One is not prevented from recovering damages for a particular harm resulting from a tort if the tortfeasor intended the harm or was aware of it and was recklessly disregardful of it, unless the injured person with knowledge of the danger of the harm intentionally or heedlessly failed to protect his own interests. 
A duty to mitigate is also a common feature of contract law. The doctrine of mitigation holds that a victim of breach of contract may not be entitled to damages that he could avoid by taking reasonable steps. ${ }^{98}$ It is "a doctrine based on fairness and common sense, which seeks to do justice between the parties in the particular circumstances of the case." "99 Although not frequently invoked in the area of intellectual property law, some courts were willing to apply the doctrine of mitigation in the area. In a recent patent case, the court held that "it is entirely appropriate for a defendant to assert a defense of failure to mitigate damages when considering what amount of compensation is appropriate," 100 and in an earlier copyright case, the court held that "[t]he mitigation doctrine of avoidable consequences is a fundamental rule of damages requiring the injured party to take advantage of reasonable opportunities to minimize his damages and avoid or prevent loss."101

Examples of duties to take action-failure of which may result in losing one's entitlement to a stronger relief-may be found not only in tort and contract law, but also in property law, and in rules governing the legal process. Adverse possession is the most obvious example in property law, ${ }^{102}$ but numerous other examples rejecting a "sit back, do nothing" approach exist, including a landowner's potential liability for injuries inflicted on

RESTATEMENT (SECOND) OF TORTS \ 918.

98. Brit. Westinghouse Elec. \& Mfg. Co. v. Underground Elec. Rys. Co. of London, [1912] 1 A.C. 673 (H.L.) 689 ("The fundamental basis is thus compensation for pecuniary loss naturally flowing from the breach; but this first principle is qualified by a second, which imposes on a plaintiff the duty of taking all reasonable steps to mitigate the loss consequent on the breach, and debars him from claiming any part of the damage which is due to his neglect to take such steps.”).

99. See Southcott Estates Inc. v. Toronto Catholic Dist. Sch. Bd., [2012] SCC 51, ๆ 25 (Can.).

100. IMX, Inc. v. E-Loan, Inc., 748 F. Supp. 2d 1354, 1361 (S.D. Fla. 2010) (rejecting the plaintiff's contention that a mitigation of damages defense does not exist in patent law and noting that although "[s]uch a defense may rarely be relevant in a patent infringement case ... it is not inappropriate").

101. Gener-Villar v. Adcom Group, Inc., 560 F. Supp. 2d 112, 133 (D.P.R. 2008). However, the court there found that the plaintiff sufficiently mitigated his damage by objecting to the defendant's acts. Id. at 134.

102. See Lydia Loren, Abandoning the Orphans: An Open Access Approach to Hostage Works, 27 Berkeley TeCH. L.J. 1431 (2012); see also Aryeh L. Pomerantz, Obtaining Copyright Licenses by Prescriptive Easement: A Solution to the Orphan Works Problem, 50 JuRIMETRICS 195, 204-05 (2010); Matthew W. Turetzky, Applying Copyright Abandonment in the Digital Age, 2010 DukE L. \& TECH. REV. 19, 24 (2010). 
trespassers, notice requirements, ${ }^{103}$ and the doctrines of abandonment ${ }^{104}$ and prescriptive easement. ${ }^{105}$

In civil litigation, duties to take action underlie limitation periods, ${ }^{106}$ or the doctrine of laches. ${ }^{107}$ They encourage litigants to act sooner rather than later to vindicate their rights, and thereby reduce costs of uncertainty, opportunism, and protracted litigation. ${ }^{108}$ Rules of civil procedure are also quite averse to a problem that we may describe here as "orphan defendants." Even though normally a plaintiff needs to serve his complaint on the defendant personally, ${ }^{109}$ the fact that a defendant is unlocatable does not necessarily bar the court from issuing a judgment against an unlocatable defendant where an alternative to personal service is permitted. ${ }^{110}$ If personal or alternative service is impractical, a court may make an order for substituted service" 111 or "where necessary in the interest of justice, may dispense with service."112 If the defendant emerges she may have some limited opportunity to set aside a default judgment "on such terms as are just," 113 but otherwise sitting back and doing nothing may lead to serious consequences to the orphan defendant.

The point here is not to argue that each of these rules maps directly onto the orphan works problem and provides a ready-made doctrinal solution. Obviously many of them, developed in other contexts, may not immediately apply, or may require various adaptations. Instead, the point is to emphasize what many of these rules have in common: a recognition that the law often discourages a sit back, do nothing approach and often encourages least-costs avoiders to take action by creating consequences for inaction.

103. See Herbert J. Hovenkamp, Notice and Patent Remedies, 88 TEXAS L. REV. 221, 22427 (2011), available at http://texaslrev.com/sites/default/files/seealso/vol88/pdf/88Texas LRevSeeAlso221.pdf.

104. See Loren, supra note 102; Turetzky, supra note 102.

105. See Loren, supra note 102; Pomerantz, supra note 102, at 220-22.

106. See, e.g., Limitations Act, S.O. 2002, c. 24, s. B (Can.), available at http://www.elaws.gov.on.ca/html/statutes/english/elaws_statutes_02124_e.htm (last visited June 28, 2012).

107. See M.(K.) v. M.(H.), [1992] 3 S.C.R. 6 (Can.).

108. Id.

109. See, e.g., Ontario Rules of Civil Procedure, CANLII, RRO 1990, Reg 194, s. 16.02, http://www.canlii.org/en/on/laws/regu/rro-1990-reg-194/latest/rro-1990-reg-194.html (last visited May 8, 2012).

110. Id. s. 16.03 .

111. Id. s. 16.04 .

112. Id.

113. Id. s. 19.08 . 
E. Judicial Authority to Tweak Remedies

A possible objection to remedy tweaking is that even if remedy tweaking is desirable, courts may not have the power to tweak statutory remedies unless the statute permits them to do that. Thus, a distinction might be drawn between discretionary remedies under $\iint 502$ (injunctions) ${ }^{114}$ and 503 ("[i]mpounding and disposition of infringing articles"), ${ }^{115}$ which the court may order, and remedies under $\int 504$ (actual damages, the infringer's profit, and statutory damages) to which the copyright owner is statutorily "entitled." Therefore, the question becomes whether courts can apply common law principles in determining remedies under $\int 504$. A full exploration of this question is beyond the scope of this Article, and if the answer is no, then this Article should be read as providing reasons for statutory reform. However, the answer may be yes for at least the following reasons:

First, it is an established principle of statutory construction that "where Congress uses a common-law term in a statute, we assume the term comes with a common law meaning, absent anything pointing another way."117 This would suggest that the copyright owner's entitlement to damages and accounting for profits under $\int 504$ ought to be subject to established principles applying to those remedies under the common law. These may include doctrines that limit those remedies, such as mitigation. As noted above, some courts have taken it for granted that the principle of mitigation applies to damages for infringement of intellectual property. ${ }^{118}$

Similarly, despite the choice of the word "entitled," at least one court has held that accounting for profit "had been given in accordance with the principles governing equity jurisdiction, not to inflict punishment but to

114. 17 U.S.C. \502(a) (2010) ("Any court having jurisdiction of a civil action arising under this title may ... grant temporary and final injunctions on such terms as it may deem reasonable to prevent or restrain infringement of a copyright'); see also eBay Inc. v. MercExchange, 547 U.S. 388, 392-93 (2006) (confirming the discretionary nature of injunctions).

115. 17 U.S.C. $\int 503(a)(1)$ ("At any time while an action under this title is pending, the court may order the impounding, on such terms as it may deem reasonable . ...”); 17 U.S.C. $\int 503$ (b) ("As part of a final judgment or decree, the court may order the destruction or other reasonable disposition ....”).

116. 17 U.S.C. S 504(b) (2010) ("The copyright owner is entitled to recover the actual damages suffered by him or her as a result of the infringement, and any profits of the infringer that are attributable to the infringement ....").

117. See Microsoft Corp. v. i4i Ltd., 131 S. Ct. 2238, 2245 (2011) (internal quotations and citations omitted).

118. See supra notes 100, 101 and accompanying text. 
prevent an unjust enrichment."119 This should justify denying (or reducing) the award of profits when the rationales underlying this remedy do not exist. In Taylor v. Meirick, ${ }^{120}$ Judge Posner explained that the purpose of this remedy is to discourage infringement and encourage users to seek permission and facilitate voluntary exchange. ${ }^{121}$ This rationale does not hold when it is prohibitively costly to seek permission and voluntary exchange is impossible. Another rationale of preventing unjust enrichment is "to prevent the infringer from unfairly benefiting from a wrongful act." ${ }^{122}$ While a user of an orphan work may benefit from a wrongful act, it is questionable whether she benefits from it "unfairly." When seeking permission would be unreasonable under the circumstances and the only alternative to the unauthorized use is not to use at all-an alternative that leaves the user and society worse off, and the owner no better off-it is quite difficult to characterize the act as unfair.

Second, and consistent with the first point, courts have not hesitated to apply common law principles of liability in copyright cases even when they have no statutory basis. For example, in Sony Corp. of America v. Universal City Studios, ${ }^{123}$ the Court held that:

The absence of ... express language in the copyright statute [that renders a person liable for the infringing acts of another] does not preclude the imposition of liability for copyright infringements on certain parties who have not themselves engaged in the infringing activity. For vicarious liability is imposed in virtually all areas of the

119. See Sammons v. Colonial Press, 126 F.2d 341, 346 (1st Cir. 1942) (citing Sheldon v. Metro-Goldwyn Pictures Corp., 309 U.S. 390, 399 (1940)). Even though these cases were decided under the 1909 Copyright Act, there is nothing to suggest that Congress changed the nature of this remedy when it enacted the present Act in 1976. See Kenneth E. Burdon, Accounting for Profits in a Copyright Infringement Action: A Restitutionary Perspective, 87 B.U. L. REV. 255, 270 (2007) (explaining that the "restitutionary theory" of the 1909 Act remained unchanged after the Act's revision in 1976).

120. Taylor v. Meirick, 712 F.2d 1112 (7th Cir. 1983).

121. More specifically, Judge Posner noted the following:

By preventing infringers from obtaining any net profit it makes any would-be infringer negotiate directly with the owner of a copyright that he wants to use, rather than bypass the market by stealing the copyright and forcing the owner to seek compensation from the courts for his loss. Since the infringer's gain might exceed the owner's loss, especially as loss is measured by a court, limiting damages to that loss would not effectively deter this kind of forced exchange.

Id. at 1120 .

122. H.R. Rep. No. 94-1476, at 161 (1976), reprinted in 1976 U.S.C.C.A.N. 5659, 5777; see also Burdon, supra note 119, at 267-71.

123. 464 U.S. 417 (1984). 
law, and the concept of contributory infringement is merely a species of the broader problem of identifying the circumstances in which it is just to hold one individual accountable for the actions of another. ${ }^{124}$

Absent an express statutory mandate, it would be a strange outcome if general principles and concepts of liability that exist throughout the law could only be used to expand the scope of liability when justified, but not to contract it when appropriate. Such an outcome is also inconsistent with earlier and current case law. For example, in Lawrence v. Dana, the court noted that even when copying exceeds the limits of fair use, "cases frequently arise in which, though there is some injury, yet equity will not interpose by injunction to prevent the further use, as where the amount copied is small and of little value, if there is no proof of bad motive, or where there is wellfounded doubt as to the legal title, or where there has been long acquiescence in the infringement, or culpable laches and negligence in seeking redress, especially if it appear that the delay has misled the respondent." ${ }^{\text {"25 }}$ Very recently, the Ninth Circuit barred copyright infringement claims on the basis of the equitable doctrine of laches. ${ }^{126}$

In sum, remedy tweaking can provide a common law solution to the orphan works problem. First, remedy tweaking recognizes that the orphan works problem is a supply-side problem just as it is a demand-side problem. It is not only a problem of users unable to locate owners, but of owners' suboptimal investment in maintaining themselves locatable. A solution for the orphan works problem that seeks to preserve copyright's market orientation needs to take into account the incentives that users and owners face and allocate the cost of maintaining a market system between users and owners.

Second, remedy tweaking takes into account the information that each of the user and the owner possesses. Remedy tweaking assumes that the user has the best information about his contemplated use and therefore should take reasonable steps to communicate his plans to the owner by seeking permission. The owner, on the other hand, has the best information about her identity and how she can be reached, and therefore should take reasonable steps to make this information available to potential users. A strict permission-first rule, which ignores the owner's ability to take steps to maintain themselves locatable, puts the entire risk on users and leads to

124. Id. at 435 (internal citations omitted).

125. 4 Cliff. 1, 61 (C.C. Mass. 1869).

126. See Evergreen Safety Council v. RSA Network Inc., 697 F.3d 1221 (9th Cir. 2012); Petrella v. Metro-Goldwyn-Mayer, Inc., 695 F.3d 946 (9th Cir. 2012). 
suboptimal utilization of works. By recognizing that copyright owners should have a duty to maintain themselves locatable and by tweaking the remedies available to them if they fail to fulfill this duty, courts can adjust the user's duty to seek ownership information and permission with a corresponding duty of the owner to provide such information. Doing that will shift some of the risk of using orphan works from the user to the owner, encourage owners to take measures to reduce the extent of the problem, and encourage greater utilization of works.

Finally, remedy tweaking leads to an important conclusion: while it may be convenient to talk about an "orphan works problem," it may be more accurate to recognize that we are indeed facing a more general problem of how to calibrate owners' and users' correlative rights and duties over a continuum and in a wide range of circumstances. In many cases "permission first" is a sensible rule, and when it is sensible, copyright owner can sit back and do nothing. Yet in other cases, a copyright system, like any other system of private ordering, cannot function effectively without imposing some duties on owners. ${ }^{127}$ It would not be an anomaly, where appropriate, to require copyright owners to maintain information about how they can be reached, to send take-down notices when they do not want their works to be used in a particular way, or to adopt simple and effective measures to communicate their wishes.

With these observations and conclusions, this Article now examines and critiques other solutions to the orphan works problem.

\section{QUASI-DOGMATIC AND DOGMATIC SOLUTIONS}

This Part canvasses and critiques current proposed solutions to the orphan works problem, which can be viewed as "dogmatic." To some degree or another, all of them ignore the fact that the orphan works problem is of the copyright owners' own making, and instead focus exclusively on the users. This Part begins with a discussion of the U.S. Copyright Office proposal from 2006, which despite being similar to this Article's proposed remedy-tweaking solution, contains some elements that place it on the dogmatic side. Next this Part discusses Canada's statutory orphan works regime, as well as collective licensing and extended collective licensing.

127. See generally Lisa M. Austin, Possession and the Distractions of Philosophy, in Philosophical Foundations of Property Law, (J.E. Penner \& Henry Smith, eds., forthcoming, 2013), available at http://ssrn.com/abstract $=2062289$ (last visited Nov. 4, 2012) (arguing that every system of private ownership requires a method of allocating title and that this must conform to the rule of law demand that it be sufficiently public). 


\section{A. The U.S. Copyright Office Remedy Tweaking Proposal}

Following extensive examination, ${ }^{128}$ in 2006 the Copyright Office issued its Orphan Works Report ("Report"). ${ }^{129}$ The Report recommended statutory reform to limit the scope of remedies available against defendants who were unable to locate the copyright owner of a work after a "good faith, reasonably diligent search." "130 The proposed statutory language is highly similar to this Article's proposal, and, if implemented, could be used as a model for this Article's proposal as well; there are many uses where there would be hardly any difference between the Copyright Office's proposal and the proposal in this Article. However, despite the similarities, this Section identifies some differences between the Report and this Article's proposal that reflect the copyright dogma's influence on the Report.

The first major difference is that the Report does not recognize copyright owners' contribution to the problem and their ability to minimize it. While it explains in detail why works become orphans and the problems of identifying and locating copyright owners, ${ }^{131}$ the Report fails to acknowledge the fact that the orphan works problem is of copyright owners' own making, and that generally, copyright owners are the problem's least-cost avoiders. The only instance where the Report seems to acknowledge the owner's ability to avoid the problem is when it discussed whether to adopt a formal approach or a case-by-case approach. ${ }^{132}$ It mentioned an argument made by Save the Music \& Creative Commons that a formal approach is justified because "it places the burden of keeping contact information current on the party best able to bear it: the owner of the copyright." 133

Eventually, the Report adopted a case-by-case approach. This approach attracted support for two different reasons. One was that "the definition of a reasonable search will vary greatly depending on the category of the work, and it will be impossible to prescribe ex ante the searches that will be

128. See David R. Hansen, Orphan Works: Mapping the Possible Solution Spaces 2 (Berkeley Digital Library Copyright Project, White Paper No. 2, 2012), http://ssrn.com/paper= 2019121 (last visited June 23, 2012).

129. See supra note 49.

130. Id. at 127.

131. Id. at $21-29$.

132. Id. at 72 n.217 ('Under a 'case-by-case' standard, the user's search is judged on a case-by-case basis, i.e. the adequacy of a search for an owner is considered ad hoc, with reference to the circumstances prevailing at the time of the search. Under the 'formal' approach, there is a pre-set list of required searches, and once the user performs those searches without success, the work is deemed orphaned.").

133. Id. at 72 . 
adequate for each category. ${ }^{134}$ To the extent that the Report adopted the caseby-case approach for its flexibility and adaptability, the choice is consistent with my proposal, ${ }^{135}$ and it is possible that despite the lack of explicit recognition of copyright owners' contribution to the problem, courts would take that into account when deciding whether the user's search was reasonable. Indeed, as Professor Lessig suggested, courts could interpret the limitation on remedies as an "implicit recognition that copyright owners have a responsibility to help make the copyright system function more efficiently ... [and] that the copyright owner bears some burden (the burden of maintaining accessibility) as a condition of getting the full benefits of copyright law's protection.",136

However, the Report also objected to the formal approach on the grounds that it would constitute "a dramatic reversal of the current copyright regime, in which an owner need not perform any positive act to preserve his rights." 137 This statement, of course, is a clear articulation of the dogma. Therefore, since neither the Report nor the proposed statutory language explicitly recognize that copyright owners should bear some of the burden of making the system work more efficiently, there is no guarantee that judges would follow Professor Lessig ${ }^{138}$ and recognize this implicit duty. Instead, like Judge Chin, they may resort to a dogmatic impulse, refuse to recognize such a duty without clear mandate from Congress, and decline to interpret the proposal as providing them such mandate. In fact, they might even conclude that the proposal consciously declined to recognize such duty.

Consider the following example: as noted in the Report, "if a well-known and comprehensive voluntary registry of owners existed in a particular industry or for a particular type of work, presumably any 'reasonable search' for the owner would include a search of that registry." 139 It is not clear, however, what the implications of this statement are. The statement may suggest that consulting such registry is a necessary condition in the sense that if such a registry exists and consulting it would allow the user to locate the

134. Id.

135. Id. at 113 ("We believe the truly 'ad hoc' system-where users simply conduct a reasonable search and then commence use, without formality-is the most efficient way to proceed.").

136. See Lawrence Lessig, Letter from Stanford LaW Professor Lawrence LESSIG TO THE HON. ZOE LOFGREN (2006), available at http://www.lessig.org/blog/ archives/20060306-lofgren.pdf.

137. REGISTER OF COPYRIGHTS, supra note 49, at 72 (citing the objection of the National Music Publishers' Association, Inc. \& The Harry Fox Agency, Inc.).

138. See LESSIG, supra note 136.

139. Id. at 72 n. 217 . 
owner, a user who fails to search the registry would not be eligible for any limitation on the remedy. But is consulting the registry a sufficient condition, in the sense that a user who searched the registry in vain would be entitled, as a matter of law, to a limitation on the remedy? Holding that consulting the registry would be a sufficient condition implicitly recognizes that an owner has a duty to register his works in that registry, and that failing to comply with this duty would limit the remedies available to him. Since the Report discusses only what is reasonable for users to do and falls short of explicitly mentioning any corresponding duties on owners, it may be perfectly open to a court to conclude that consulting the registry may be a necessary condition but not a sufficient one, and that since the owner has no duty to register, a diligent user should have taken additional measures to search the registry.

More generally, because the Copyright Office proposal overlooks the owners' side, it provides an ad hoc solution to a specific problem without explaining how it fits within the general juridical order of which copyright law is a part. As a result, judges may not feel confident to apply the proposal liberally and instead may treat it as an exception that should be interpreted narrowly.

Another difference between the Report and this Article's proposal, which also stems from ignoring the owners' contribution to the problem, is that the Copyright Office proposal encourages a tendency to treat orphan works as a question of status rather than a problem that exists on a continuum. The proposal explicitly refers to the "designation of a work as orphaned," "140 and then turns to identify the criteria for such designation. ${ }^{141}$ The result is that a work either qualifies as orphaned - triggering the limitation on remedies-or does not qualify, in which case no limitation whatsoever is permitted. The result is a crude dichotomy that can produce dramatically different outcomes in similar cases. ${ }^{142}$ For example, suppose that two users contemplate similar projects. Both of them make good faith, albeit unsuccessful, efforts to locate the owner, but User A pursued one additional search, while User B did not. Now, suppose that the owner emerges and sues both of them; User A, who pursued that additional search, is able to convince the court that he was reasonably diligent, whereas User B is found to have been not diligent enough. The result is that User A may be protected from harsh remedies, while User B may be just as liable to the full panoply or remedies as if he were the worst offender who conducted no search at all. The possibility that

140. Id. at 71 .

141. Id. at $71-83$.

142. Admittedly, a similar problem exists under the fair-use doctrine. See Kozinski \& Newman, supra note 33. 
minor non-consequential differences in the facts of similar cases will result in dramatic differences in the outcome runs against deep notions of the rule of law. ${ }^{143}$ Moreover, such outcomes are even more difficult to justify if the owner could have easily made it possible for both users to locate her but failed to do so.

Lastly, the Copyright Office's proposal contains some prerequisites that may introduce rigidity in a place where flexibility is required. For example, the limitation on the remedy may only be available when the user performed a good faith and reasonably diligent search to locate the owner prior to copying the work. While normally seeking the owner prior to using the work is a justified requirement, there are situations in which using the work while continuing to try and locate the owner does not seem objectionable. ${ }^{144}$ It is easier to reach this conclusion when acknowledging that owners are at least partly responsible for the difficulty of locating them. This aspect of the Copyright Office's proposal is another reflection of its exclusive focus on the behavior of users, and the underlying influence of the dogma.

This Article's proposal avoids these problems because it does not seek to designate a status of an orphaned work. Instead, it recognizes that the locatability of the owner is a question of degree and that the concept of an orphan work is a relative one. Locating the owner of almost any work requires some effort, and very few works, if any, are truly orphaned in the sense that even with unlimited resources it would be impossible to track their owners. Therefore, within this Article's proposed framework, saying that a work is orphaned simply means that under the circumstances of a particular case, the user should not have exerted additional effort to locate the owner and that the owner's inaction justifies a limitation on the remedies. Thus, the term "orphan" is simply the conclusion of the analysis rather than a prerequisite designation.

Despite its shortcomings, the Copyright Office's proposal, had it been adopted, would have in practice allowed judges considerable latitude to implement it in a way that is consistent with my approach. While its exclusive focus on users and lack of attention to owners' contribution to the orphan work problem reflect the dogma, it is significantly better than other proposed solutions that are truly captive of the dogma, such as those discussed in the next Section.

143. Cf. David A. Strauss, Must Like Cases Be Treated Alike? (U. Chi. Pub. Law \& Legal Theory, Working Paper No. 24, 2002), available at http://ssrn.com/paper $=312180$ (last visited June 25, 2012).

144. Consider the example of the Dutch broadcasters. See Van Gompel, supra note 52. 


\section{B. CANADA'S ORPHAN WORKS REGIME}

In 1988, as part of a major reform to its Copyright Act, Canada introduced a novel mechanism for dealing with the orphan works problem. ${ }^{145}$ Section 77 established a mechanism allowing prospective users of a work to obtain a license to use it from the Copyright Board when they cannot locate the owner. ${ }^{146}$ The section provides that "[w]here, on application to the Board by a person who wishes to obtain a licence to use [a published work] ... in which copyright subsists, the Board is satisfied that the applicant has made reasonable efforts to locate the owner of the copyright and that the owner cannot be located, the Board may issue to the applicant a licence to [use the work]." ${ }^{147}$ Such license is non-exclusive and is subject to such terms and conditions as the Board may establish. ${ }^{148}$ If the Board issues such a license, the copyright owner may, no later than five years after the expiration of the license, collect the royalties fixed in the license or, in default of their payment, commence an action to recover them in a court of competent jurisdiction. ${ }^{149}$

145. See Jeremy De Beer \& Mario Bouchard, Canada's 'Orphan Works' Regime: Unlocatable Copyright Owners and the Copyright Board, 10 OxFORD U. COMMONWEAlth L.J. 215, 220 (2010).

146. Copyright Act, R.S.C. 1985 , c. C-42, s. 77.

147. Id. s. 77(1).

148. Id. s. 77(2).

149. Id. s. 77(3). The entire section reads as follows:

77. (1) Where, on application to the Board by a person who wishes to obtain a licence to use

(a) a published work,

(b) a fixation of a performer's performance,

(c) a published sound recording, or

(d) a fixation of a communication signal

in which copyright subsists, the Board is satisfied that the applicant has made reasonable efforts to locate the owner of the copyright and that the owner cannot be located, the Board may issue to the applicant a licence to do an act mentioned in section 3, 15, 18 or 21 , as the case may be.

(2) A licence issued under subsection (1) is non-exclusive and is subject to such terms and conditions as the Board may establish.

(3) The owner of a copyright may, not later than five years after the expiration of a licence issued pursuant to subsection (1) in respect of the copyright, collect the royalties fixed in the licence or, in default of their payment, commence an action to recover them in a court of competent jurisdiction.

(4) The Copyright Board may make regulations governing the issuance of licences under subsection (1).

Id. s. 77 . 
At first glance, this solution looks attractive, and appears to provide a pragmatic and balanced solution. This statutory mechanism recognizes that when the owner cannot be located, adhering to the permission-first rule would prevent works from being used for socially beneficial purposes, and that such an outcome is inconsistent with the purpose of the Copyright Act. Accordingly, it provides a solution by allowing the Copyright Board to issue a compulsory license that authorizes the use of a work when its owner cannot be located. However, a license will not be available unless the user made reasonable efforts to locate the owner. If the owner is locatable but refuses to negotiate or grant a license, no license will issue. ${ }^{150}$ Even if the owner does not respond to any request by the user, no license will issue, as long as the owner is locatable. ${ }^{151}$

While the mechanism rewards the diligent user by granting a license, thereby immunizing him from any future claim by the owner should she emerge, it also considers the interests of the owner. The Board does not simply immunize the user from future liability. Rather, it fixes royalties that the users should pay, and may determine other terms and conditions. Although the owner cannot get the money as long as he is unlocatable, the mechanism provides that the owner, should he appear, and within five years after the expiry of the license, may collect the royalties from the user, and in the case of default of their payment, commence an action to recover them. Thus, rather than suing for copyright infringement (and prevailing in such a suit) and being subject to the standard three years limitation period beginning at the time of the reproduction, the owner only needs - if the user refuses to pay-to commence an action for a recovery of a debt, and can do that within a longer period, five years after the expiry of the license. The user, however, does not have to pay unless and until the owner demands payment, and therefore, in the not-unlikely event that the owner never shows up, the user does not have to pay anything while minimizing the risk of liability to zero. All in all, this mechanism seems to provide not only a pragmatic solution to the orphan works problem, but a solution that deviates as little as possible from the market mechanism, and from the bilateral relations that lie at the heart of copyright. ${ }^{152}$

However, this solution only seems pragmatic until one considers it more carefully, and further, until one pays close attention to how the Board implements it. First, even though the statute may not strictly mandate this, the Board created a quasi-judicial procedure: not only must the user apply for

150. De Beer \& Bouchard, supra note 145, at 226.

151. Id.

152. See supra Part III. 
a license, she must also establish that the statutory requirements exist. ${ }^{153}$ This creates an apparent anomaly: whereas scores of commercially available and highly valuable works are licensed every day through streamlined simple procedures without ever involving anything that resembles a judicial procedure (consider iTunes), and whereas only a small number of them might ever be litigated, the use of orphan works, which are almost by definition works with very little commercial value, requires a much more costly quasi-judicial procedure. This seems to be a totally inefficient use of users' private resources and of the Board's public resources.

In addition to this fundamental anomaly, the Board's implementation adds additional layers of complexity, which heighten the burden on the user. Since section 77(1) refers to a "published work," 154 the Board takes the view that it could not issue a license unless the user demonstrates that the work had indeed been published. On this basis, the Board refuses to issue licenses when applicants could not provide evidence that the work had been published. In one case the Canadian Centre for Architecture in 2004 wished to reproduce and display three photographs taken in 1955, 1957, and 1967 and found at the Public Archives of Canada, for the purpose of an exhibition entitled Les années 60: Montréal voit grand ("The 60's: Montreal Thinks Big"). ${ }^{155}$ In another case the same year, the Office of the Lieutenant Governor of Québec wished to reproduce a photograph taken on the opening day of the November 1959 legislative session in a book on the history of lieutenant governors of Québec. ${ }^{156}$

Second, while the Act provides that the Board must be satisfied that the applicant has made reasonable efforts to locate the owner of the copyright and that the owner cannot be located, the Act does not specify what ought to satisfy the Board. ${ }^{157}$ Arguably, it would be open to the Board to adopt a very minimal threshold. For example, it could be enough for an applicant to fill an online form and click "I Agree" below a declaration that she made reasonable efforts to locate the owner and could not locate him, and if that seems too easy, a sworn declaration of the same could suffice to satisfy the Board. The Board, however, chose to require much more than that. In the

153. De Beer \& Bouchard, supra note 145 , at 226.

154. Copyright Act, R.S.C. 1985, c. C-42, s. 77(1) (Can.).

155. Copyright BoARd CANADA, 'RE CANADiAn CENTRE FOR ARCHITECTURE' 2004UO/TI-32 (Jan. 17, 2005), http://www.cb-cda.gc.ca/unlocatable-introuvables/other-autre/ 3-b.pdf.

156. Copyright BoARd CANADA, 'RE OfFice of THE LiEutenAnt Governor OF QUÉBEC’ 2004-UO/TI-37 (Mar. 3, 2005), http://www.cb-cda.gc.ca/unlocatableintrouvables/other-autre/4-b.pdf.

157. Copyright Act, R.S.C. 1985, c. C-42, s. 77(1). 
past, the Board required applicants to file an affidavit detailing all of the steps undertaken to locate the copyright owner, in addition to other supporting documents. ${ }^{158}$ Even though these requirements have been relaxed, the Board now requires much more than a declaration. According to De Beer \& Bouchard:

The Board generally expects an applicant to have consulted most of the repertoires of copyright licensing agencies and collective societies, as well as national libraries' indices, copyright offices' registration records, publishing houses and corporate records. Comments made to the US Copyright Office indicated that users sometimes search on the internet, in old phone books and through death certificates and estate records. An applicant will be required to extend the search beyond Canadian borders if it is probable that the owner of the copyright may be located abroad. ${ }^{159}$

Since the Act itself provides very little guidance on how the regime should work, the way the Board perceives its role is paramount. The Board emphasizes that the Act uses the terms "may issue a licence," and not "shall issue," giving it wide discretion. ${ }^{160}$ According to the Board, it "is not under a strict obligation to issue a licence even if all the conditions have been met." Apparently, the Board does not consider itself as a facilitator, but as a custodian, "stepping into the shoes of the absent copyright owner." 162 This means that the Board does not limit its discretion to preventing possible and foreseeable prejudices to the unrepresented party, as courts in ex parte proceedings normally do, but instead, the Board takes upon itself to represent the interests of the unlocatable owner. ${ }^{163}$ This approach inevitably complicates the mechanism. Although the Board may not usually conduct a formal hearing, it may deliberate, and it may issue a reasoned decision. In addition, the Board may refuse to grant a license not because the owner was actually locatable, but because the Board concluded that the use does not actually infringe any exclusive right of the owner and therefore no license is necessary and issuing one would be ultra vires the power of the Board. ${ }^{164}$

158. See De Beer \& Bouchard, supra note 145, at 220-31 (describing the various requirements).

159. Id. at 228 .

160. William Vancise J., COPyright BoARd of CANADA, SpeECH GIVEN By THE Honourable Justice William J VANCise, Chairman of THE COPyright BoARd of CANADA 6 (2007), available at http://www.cb-cda.gc.ca/about-apropos/speechesdiscours/20070815.pdf.

161. Id.

162. Id.

163. De Beer \& Bouchard, supra note 145, at 230.

164. Id. at 223 . 
Sometimes, the Board members may disagree with each other, and a written decision with a majority and dissenting opinions would issue. ${ }^{165}$ All of this is costly.

The record of decisions made under section 77 suggests that in practice the mechanism is nothing but an esoteric phenomenon. De Beer \& Bouchard report that during the period between 1990 (after section 77 came into force) and 2008-2009 $9^{166}$ the Board opened 441 files pertaining roughly to 12,640 different works. ${ }^{167}$ Out of these applications, $52.2 \%$ resulted in a decision (by the end of 2008, the Board granted 230 licenses and denied 5 applications), in $22.2 \%$ of the cases the owner was found, $16.3 \%$ of the applications were withdrawn, while $8.6 \%$ were not followed up. ${ }^{168}$ On average, then, the Board granted at least 12 licenses per year. The total license fees set by the Board during the first 18 years of the regime was just under C \$70,000 (Canadian dollars). ${ }^{169}$ The figure excludes some types of licenses, estimated to have generated royalties not exceeding a few thousand Canadian dollars. ${ }^{170}$ Assuming that the total figure is $\mathrm{C} \$ 75,000$ (or $\mathrm{C} \$ 4,167$ annual average), the average license fee for each license was $\mathrm{C} \$ 326$. The average is skewed upwards, because " $65 \%$ of applicants sought to use only 1 work, $24 \%$ applied to use between 2 and 10 works and $7 \%$ applied to use between 11 and 100. Some applicants have sought licenses for scores of works at the same time[, while] [i]n a handful of cases, applications were made for a license or licenses covering thousands of works."171

It is impossible, of course, to know how many orphan works were copied in Canada without obtaining a license from the Board (either because users are ignorant of the mechanism, or prefer risking liability over incurring the cost of applying and complying with a license), or how many uses were forgone despite the ability to obtain such a license (either because users are ignorant of the mechanism, or because they prefer foregoing the use over incurring the cost of applying and complying with a license). Yet the record

165. Copyright BoARd CANAda, 'RE BreakTHROUgh FILMS \& TELEVISION’ 2004UO/TI-33 (Mar. 6, 2006), http://www.cb-cda.gc.ca/unlocatable-introuvables/licences/ 156r-b.pdf.

166. The report is not entirely clear about the exact period. The authors state: "The cutoff date for analysis is the end of the 2008 calendar year, although some 2009 data has been included where available and appropriate." De Beer \& Bouchard, supra note 145, at 242.

167. Id. at 242. A significant amount of these applications pertained to copying of architectural plans in municipalities' archives (needed, for example, for building permits). In 2007, the Board concluded that no license is needed to copy those. Id. at 242 n.127.

168. Id. at 243-44.

169. Id. at 251 .

170. Id.

171. Id. at 242-43. 
so far makes it very difficult to call the section 77 mechanism a success story. Common sense strongly suggests that an average of twelve licenses per year represents a small droplet in a bucket of the actual or potential uses of orphan works in an economy of the size of Canada. The mechanism presumably has been beneficial for the applicants who obtained licenses, yet one cannot help but wonder whether the mechanism is worth preserving. The costs of maintaining the regime (for the applicants and for Canadian taxpayers) likely exceed the amount of license fees that it has generated, and even the cost of applying and processing a license likely exceeds the average license fee. It could be suggested that streamlining the procedure and increasing awareness would lead to wider utilization of the mechanism, but the very low adoption rate likely reflects a more endemic problem. It is possible that, almost by definition, the cost of the mechanism would be higher than the license fees that it would generate, no matter how streamlined the procedure is and regardless of the rate of the license fees. ${ }^{172}$ That is because the mechanism ignores the root cause of the orphan works problem: the fact that the cost of maintaining themselves locatable exceeds the license fees that owners expect to earn. If it is inefficient for owners to administer their rights under these conditions, it is unclear why the Board would be able to do that at a lower cost.

If the Canadian orphan works regime has not and cannot really provide any real solution to the orphan works problem, one cannot help but wonder what was the point in adopting and what is the point in maintaining it. Possibly, the answer is that rather than solving the orphan works problem, the purpose of the Canadian mechanism is to enshrine the dogma. Although, collaterally, in some cases, with the help of the Board, applicants were eventually able to locate the owners, ${ }^{173}$ this is not the goal of the mechanism. Nor is there any evidence that where licenses were granted the money was

172. The license fees set by the Board are probably excessive. First, according to De Beer \& Bouchard, " $[t]$ he Board often asks collective societies for up-to-date information on the price they charge to licence their own repertoire for proposed uses of particular types of works. In markets where collective administration does not exist, it is often possible to determine a generally recognised market practice." Id. at 235. Since the prices that are set by collective societies often reflect their monopolistic position and absence of competition, using their prices are a poor proxy for the license fees that an owner and user would agree on in an arms-length competitive negotiations. Second, using prices set for non-orphan works as a proxy for the price of orphan works is misguided because, as noted above, the reason why the work is orphan is that the owner does not expect to earn license fees that exceed the cost of licensing. That is, rather than relying on the revealed preferences of other copyright owners, the Board should have relied on the preferences of the copyright owner, who effectively revealed that she does not expect to earn any meaningful license fees.

173. Id. at 243 . 
actually collected by the owners. The mechanism does not solve the orphan works problem in the sense of matching between users and owners. Instead, the mechanism offers users that are either extremely risk averse or are devote believers in the copyright dogma an ability to obtain indulgence, while entrenching the notion that using work is a sin, and any benefit derived from it is sinful.

The clearest indication that the section 77 mechanism is-or at least has become-an instrument for the sale of indulgences is the Board's controversial practice of ordering licensees to pay license fees to a collecting society. ${ }^{174}$ Under section $77(3)$ :

The owner of a copyright may, not later than five years after the expiration of a licence issued pursuant to subsection (1) in respect of the copyright, collect the royalties fixed in the license or, in default of their payment, commence an action to recover them in a court of competent jurisdiction. ${ }^{175}$

The implication is that a user who successfully applies for a license becomes immune from an infringement action, and is only liable to pay the license fees determined by the Board if, and only if, the copyright owner emerges within five years after the expiry of the license. If the owner never shows up, as might be expected (or shows up later than five years after the expiry of the license), the user will not be required to pay anything, will be liable for nothing, and will be under no obligation to share the benefit arising from using the work. Nor does the user have to hold the license fees in trust or pay an escrow. The owner, in return, benefits from an extended limitation period, and from an ability to recover the license fees in an expeditious process (instead of suing for infringement) should the user refuse to pay the prescribed fees.

Despite what seems to be clear direction from Parliament that the payment is completely contingent upon the owner's emergence within five years, the Board decided to order applicants to pay copyright collectives on a non-contingent basis, immediately upon the issuance of a license. ${ }^{176}$ The Board does not even require the copyright collective to hold the license fees in trust (it did so in the past), but allows the collective to use the money as it sees fit, as long as the collective undertakes to compensate the owner if it becomes necessary. ${ }^{177}$

174. Id. at 236 .

175. Copyright Act, R.S.C. 1985, c. C-42, s. 77(1) (Can.).

176. See De Beer \& Bouchard, supra note 145, at 236.

177. Id. 
What justifies such a radical shift from the mechanism contemplated by Parliament (or, perhaps more precisely, such a subversion of that mechanism)? De Beer \& Bouchard mention the following rationales: (1) anecdotal evidence that involving collective societies in the process increases the likelihood that royalties will eventually reach the true copyright owner; (2) the possibility that it might be easier for copyright owners to collect owing amounts from a collective than from the user who might disappear; and (3) the potential to help collective societies defray some of the costs that they incur in cooperating with the Board on section 77 applications. ${ }^{178}$

These arguments are not convincing. While it seems likely that collective societies have information that can facilitate locating copyright owners, it does not follow that the collective should get paid when people use works of owners who never authorized the collective to license on their behalf. By definition, an orphan work cannot be part of the collective society's repertoire: if it were, it would not be an orphan work. At most, the fact that collecting societies might possess information that might facilitate locating owners may justify making the data that collectives have available to the public. ${ }^{179}$ Similarly, the fact that sometimes the owner might find it easier to collect the money from a collective than from the user is not self-evident, and even if it were, does not justify departure from what Parliament had contemplated. In fact, the fact that users who apply for a section 77 license may practically not pay anything is not a bug of the mechanism, but a feature, because it encourages users to apply a license. The Board's decision to require immediate upfront payment to a collective society punishes the very few applicants who actually go into the trouble and cost of applying for a section 77 license. $^{180}$

Bouchard, who is also the Copyright Board's General Counsel, in a recent paper offered additional, and more forthcoming, justifications for the

178. Id. at 238 .

179. In fact, under sections 67 and 70.13 of the Canadian Copyright Act, collective societies must answer within a reasonable time all reasonable requests from the public for information about their repertoire of works. Copyright Act, R.S.C. 1985, c. C-42, s. 67, 70.13 (Can.).

180. Theoretically, if there is no statutory basis for the Board's decision to order upfront payment to a collecting society, such an order could be set aside by the Federal Court of Appeal following an application for judicial review, see Federal Courts Act, R.S.C. 1985, c. F-7, s. 28(1)(j) (Can.). Realistically, such an application for judicial review seems very unlikely, as long as the license fees that the Board orders to pay are not excessively high, because a user who is willing to incur the cost of judicial review is probably better off not seeking a license in the first place and risk incurring the cost of litigation should the copyright owner ever emerge. 
decision to order applicants pay collective societies. ${ }^{181}$ These justifications reflect the view of the user as a sinner, and betray the Board's allegiance to the copyright dogma. Bouchard explains that the while the Board acknowledges that non-contingent royalties payable to a collective society are controversial, the Board's position is that the user must generally be required to pay because the Board "does not believe that it should be in the business of issuing free insurance policies against prosecutions for violation of copyright." ${ }^{\prime 182}$ He explains that the Board compares the user to a defendant in a class action who, after being found liable, may be disgorged of the surplus unclaimed by the class, ${ }^{183}$ a comparison that reveals how the Board treats the user as a wrongdoer whose activities should be discouraged, not facilitated. Finally, he notes that the Board relies on the concept of $y$ pres in trust law, whereby a court may order that property be used for a purpose that is as close as possible to the use originally intended if it becomes impossible to carry out the original purpose. ${ }^{184}$ Even though Parliament clearly contemplated that if the owner does not emerge the user can keep the surplus, the Board views disgorging the user of this surplus as a closer purpose because "given the choice, the unlocatable copyright owner would prefer that the royalties be paid to a group that represents interests similar to those of the owner than to see the user take advantage of the owner's copyright for free," 185 and "when a protected use of a protected work is contemplated, the payment of royalties should be the norm, not the opposite."186

These statements present some of the clearest articulations of the copyright dogma. It is far from obvious that the average copyright owner would rather funnel such fees to benefit other authors ${ }^{187}$ than be retained by the user. In fact, one could assume that many owners might actually be quite happy, if not thankful, if someone showed interest in their works after they ceased to be commercially viable and exhumed them from oblivion. The fact that the Board unequivocally assumes that the average copyright owner

181. Mario Bouchard, The Canadian Unlocatable Copyright Owners Regime, in THE COPYRIGHT BOARD OF CANADA: BRIDGING LAW AND ECONOMICS FOR TWENTY YEARS 137,153 (2011).

182. Id. at 153 .

183. Id.

184. Id.

185. Id.

186. Id. at 154.

187. Also note the subtle reference to the beneficiaries as "authors" rather than "owners" even though the main beneficiaries of fees collected by collecting societies, other than the societies themselves, tend to be publishers, not authors. 
would a priori prefer another owner over the user reflects the underlying view that any unpaid use is inherently sinful. Effectively, by requiring users who apply for a license to pay a collective society, the Board has torn apart the essential feature of copyright as a set of bilateral relationships between owners and users, and created, without any statutory mandate and contrary to the mechanism contemplated by Parliament, an extended collective licensing mechanism. The merit of that mechanism is discussed in the next Section.

\section{EXTENDED Collective LiCEnsing}

Extended Collective Licensing ("ECL") regimes have existed in some of the Nordic countries since the 1960s. ${ }^{188}$ In the aftermath of the rejection of the Amended Settlement Agreement ("ASA") in the Google litigation, ${ }^{189}$ they have gained increasing popularity as a possible solution to the orphan works problem. ${ }^{190}$ Under an ECL regime, a collecting society that represents a substantial number of rights holders may grant licenses that extend not only to copyrighted works owned by the society's members, but also, with respect to the same set of uses, to works owned by non-members. The society is typically authorized to act on behalf of foreign as well as domestic rights holders. ${ }^{191}$ In some cases copyright owners may opt out, and therefore will not be bound by the agreement entered by the collecting society, but in some other cases they cannot. ${ }^{192}$

ECL regimes were not designed to solve an orphan works problem, but ECL is considered by some to be an attractive solution for the orphan works problem because it solves the problem in one fell swoop. ${ }^{193}$ Indeed, the orphan works problem is simply assumed away, as the ECL, by definition, includes the orphan works in the collecting society's repertoire.

Moreover, ECL could be seen as a logical extension of the rationale for collective administration generally. The standard justification for collective administration of copyrights is the reduction of the transaction costs of licensing and enforcing the copyrights in situations when administering these

188. Thomas Riis \& Jens Schovsbo, Extended Collective Licenses and the Nordic Experience: It's a Hybrid but is it a Volvo or a Lemon?, 33 COLUM. J.L. \& ARTS 471 (2009).

189. Authors Guild v. Google, Inc., 770 F. Supp. 2d 666, 686 (S.D.N.Y. 2011).

190. See Samuelson, supra note 6, at 705-15; see also Robert Darnton, Jefferson's Taper: A National Digital Library, N.Y. REV. BOOKS (Nov. 24, 2011), available at http://www.nybooks.com/articles/archives/2011/nov/24/jeffersons-taper-national-digitallibrary/.

191. Riis \& Schovsbo, supra note 188 , at 475.

192. Id. at 476 .

193. See sources cited supra note 190. 
rights in a competitive market is assumed to be prohibitively costly, or at least highly inefficient. ${ }^{194}$ That is why Richard Posner calls them "benign cartels." $" 195$ Assuming that there are indeed situations where competitive administration of commercially available works is indeed prohibitively costly and collective administration is desirable, ${ }^{196}$ then it seems only to make sense to include orphan works in the collective's repertoire because the cost of those works through the market is prohibitively costly a fortiori.

Beyond this superficial appeal, however, it is doubtful whether ECL is an appropriate solution to the orphan works problem. Note that the logic of the previous paragraph does not work in reverse. If prohibitively high transaction costs in a particular industry justifies collective administration of copyrights of works whose owners are known, there is merit in extending collective administration to orphan works, because the transaction costs involved in licensing those are, by definition, even higher. However, it does not follow that when the market fails in a subset of an industry (e.g., orphan works) it makes sense to solve this failure by extending that solution to all other parts of that industry where the market works just fine. In other words, when there is, or could be, a reasonably well-functioning competitive market for non-orphans (which are, presumably, the more commercially valuable ones), it does not make sense to replace that competitive market with a monopolized structure in order to solve the problem of the orphans (which are presumably the least commercially valuable ones).

Consider the ASA, which, had it been approved, would, in effect, have created a sui generis ECL. ${ }^{197}$ The forward-looking element of the ASA consisted of two separate parts: first, it proposed to create The Book Rights Registry ("Registry"), which would be, effectively, a new collecting society for works whose copyright owners are known and locatable ("locatables"). In addition, the ASA offered a solution to the orphan books problem (books whose copyright owners are unknown or unlocatable). The first part involved a problematic solution to a problem that does not exist. The second part, however, involved a solution, albeit flawed, to a real problem. Both aspects

194. How often this happens is a separate question. See generally Ariel Katz, Copyright Collectives: Good Solution But for Which Problem?, in WORKING WITHIN THE BOUNDARIES OF Intellectual Property: InNovation Policy For The KNOWledge Society (Harry First, Rochelle C. Dreyfuss, \& Diane L. Zimmerman eds., 2009).

195. Richard A. Posner, Antitrust Law 30 (2001).

196. But see Katz, supra note 194 (questioning the prevalence of situations that justify collective administration).

197. See Samuelson, supra note 6, at 706-08 (discussing the similarities and differences between the ASA and ECL). 
were subject to an opt-out rule-namely, they would not apply to copyright owners who actively opt-out of the settlement. ${ }^{198}$

The first aspect of the ASA, dealing with the sale of locatables, is difficult to justify. The Registry would have been essentially a new collecting society with the power to collectively set the prices and terms for the sale of digital books. However, it is difficult to see why collective administration is desirable in a market for digital books. The perceived market failures that might justify collective administration in some narrow circumstances ${ }^{199}$ do not generally apply to a project like Google Books or similar projects. First, there are no prohibitive transaction costs preventing individual copyright owners and Google from transacting over the terms of commercializing their works. ${ }^{200}$ Indeed, even the smallest copyright owner could locate and contact Google if he wants to (and if he does not know how to find Google, he can google Google). Second, it is very easy for a copyright owner to monitor whether Google has used the work without authorization (he can google the work and immediately find out; he can even create a "Google Alert" and be notified automatically). ${ }^{201}$ If striking deals with locatable copyright owners works for Amazon or Apple with respect to books and sound recordings, then it should work for Google, too. ${ }^{202}$ There is no market failure that may justify collective administration (and the associated reduction in competition) in the case of in-print works (or even out-of-print works whose owners are known and locatable). Therefore, the ASA offered an anti-competitive solution to a problem that does not exist. ${ }^{203}$ The sale of digital copies of such books should be subject to copyright law's ordinary opt-in (i.e., permissionfirst) rule. ${ }^{204}$

198. AS A, supra note 2 (Attachment I, Notice of Class Action Settlement, 25).

199. See Katz, supra note 194.

200. See Randal C. Picker, The Google Books Settlement: A New Orphan Works Monopoly, 5(3) J. COMPETITION L. ECON. 383, 403 (2009).

201. Google Alerts, GOOGLE, http://www.google.com/alerts (last visited Sept. 22, 2012).

202. On October 4, 2012, Google and the plaintiff publishers in the Google Books litigation reached a settlement that allows Google to continue doing what it had done before and allows the publishers to choose whether Google will display larger parts of their books and sell copies of them. See Claire Cain Miller, Google Deal Gives Publishers a Choice: Digitize or Not, N.Y. TIMES, Oct. 5, 2012, at B7. The settlement, and the fact Google has offered such "partnership" agreements all along, confirm that there was no market failure that would hinder such transactions.

203. Picker, supra note 200.

204. The sale of digital books should not be confused with the original function of Google Books: to serve as a searchable index of books. As Sag notes, Google's scanning and caching of books for the purpose of providing a searchable index should not constitute copyright infringement at all. See Sag, supra note 48. 
The case for orphan works is different, and the part of the ASA dealing with orphan works tried to solve a real market failure. Had it been approved, the ASA would have permitted Google to sell copies of orphan works until their owners showed up and demanded otherwise. ${ }^{205}$ Meanwhile, Google would transfer $63 \%$ of its earnings from the sale of such books not to the copyright owners (because they are unlocatable), but to the Registry, which, with the aid of the Unclaimed Works Fiduciary, would attempt to locate these owners and distribute the money to them (after deducting its expenses). ${ }^{206}$ If those owners could not be found, the money would eventually be remitted to literary based charities. Effectively, the ASA contemplated an ECL regime.

One of the main objections to this aspect of the ASA was that it would effectively grant Google a monopoly over the commercial use of orphan works. ${ }^{207}$ This was a serious concern, but if the alternative to monopoly (one seller) is "nullopoly" (no seller), then a monopoly is probably the better option. ${ }^{208}$ However, presenting the question as a choice between monopoly and nullopoly is false: it assumes that the only realistic alternative to an orphan works nullopoly is a monopoly, ${ }^{209}$ and it further assumes that monopoly in the form of ECL solves the orphan works problem. But an orphan works monopoly is not the only alternative to a nullopoly because the nullopoly can be averted by other means, such as this Article's remedytweaking solution. And moreover, ECL does not really solve the problem, it only pretends to. ECL relieves some pressure off the absurd consequences of copyright dogma but a solution to market failure it is not, as the next Section explains.

205. ASA, supra note 2 .

206. Id.

207. See, e.g., Statement of Interest of the United States of America Regarding Proposed Amended Settlement Agreement at 21, Authors Guild v. Google, Inc., 770 F. Supp. 2d 666 (S.D.N.Y. 2011) (No. 05 Civ. 8136), available at http://thepublicindex.org/docs/ amended_settlement/usa.pdf ("A core issue that arises out of the parties' effort to resolve this matter is the ability of Google, and no other entity, to compete in a marketplace that the parties seek to create. Nothing in the ASA addresses this concern. . . There is no serious contention that Google's competitors are likely to obtain comparable rights independently.'”); Picker, supra note 200, at 385-86.

208. See Einer Elhauge, Why the Google Books Settlement is Procompetitive, 2 J. LEGAL ANALYSIS 1 (2010).

209. See Randal C. Picker, Antitrust and Innovation: Framing Baselines in the Google Book Search Settlement, GCP: THE ANTITRust CHronicle 5 (Oct. 2009), available at http:/ /www.law.uchicago.edu/files/ file/493-rcp-google.pdf. 


\section{Does ECL Even Solve the Orphan Problem?}

Recall that the orphan works problem stems from the inability of owners and users to transact. As discussed above, this problem has two sides: the demand side (the user) and the supply side (the owner). ECL supposedly solves the orphan works problem because it allows the user to obtain a license not from the owner, who is by definition unlocatable, but from a third party, such as a collecting society. If this option is available, then it partly solves the demand side of the problem (I say partly because the user needs to deal with a monopoly, which creates another set of problems that I address below). But requiring the user to seek permission from and pay a fee to a collecting society (or even only pay a fee) does not really solve the supply side of the problem. Instead, it only shifts the problem from one location to another: the problem of locating the unlocatables moves from the user to the collecting society. But shifting a problem does not necessarily solve it. Of course, we can pretend that it does, and as a matter of positive law, if lawmakers decide that instead of getting permission from the copyright owner a user can pay a fee to a collecting society, then the problem, as a practical matter, may be solved, but it is solved not because the solution addressed the causes of the problem but because the lawmaker decides that an act that would normally attract liability may be absolved by paying a fee to a collecting society.

Why lawmakers should adopt such a rule, however, is far from clear. Perhaps, if there were reasons to believe that the collecting society would only request the fee that the owner would have asked, and that upon payment, the money would miraculously find its way to the owner (who is, after all, unlocatable), then the collecting society would be a perfect intermediary and ECL would be a perfect solution. But realistically, it is more likely that the collecting society will not become that perfect intermediary. It is more likely that the collecting society will charge supra-competitive fees that will discourage use of orphan works, and that if any money will eventually be distributed to the copyright owner, most of the collected fees would benefit others: the collecting society's insiders, other copyright owners, or, in the case of the Fiduciary, literary-based charities. It is difficult to see how requiring users to pay a fee to someone other than the copyright owner advances the purposes of copyright. Such a payment is a windfall for the recipient, and therefore cannot provide any additional incentive to create beneficial works, ${ }^{210}$ and from the user side, such a fee constitutes an

210. See Randal C. Picker, Private Digital Libraries and Orphan Works, 27 BERKELEY TECH. L.J. 1259, 1277-79 (2012). 
additional cost, and therefore it would decrease, rather than enhance, access to and dissemination of orphan works.

ECL is an acceptable solution to the orphan works problem only if we no longer think about copyright in terms of the correlative rights and duties of owners and users and their private reordering in open markets, and stop asking how those correlative rights and duties can be exercised and complied with in ways that promote the public interest and minimize interference with the rights and liberties of others. Instead, ECL is an acceptable solution only if we define copyright solely by the prohibitions it imposes on users, if we view copying another person's work as inherently sinful, regard prior permission as the means to avoid and absolve that venial sin of copying, and admit that we may not be interested in avoiding sin as we are interested in allowing collecting societies to monetize it, through the sale of indulgences.

\section{E. ECL AS INSURANCE}

One defense of ECL is that it is a pragmatic solution, which allows riskaverse users to pay a fee and eliminate the risk of liability. Essentially, it could be argued, ECL is an insurance scheme, whereby in exchange for a fee, the collecting society relieves the user from her potential liability and assumes an obligation to pay the owner should he emerge. Yet, this insurance scheme is quite extraordinary for several reasons. First, if the law disapproves of the unauthorized use of a work by regarding such use as an infringement, it is questionable whether a contract under which one party undertakes to indemnify another for the risk of deliberate infringement is valid, because contracts that "create incentives to commit acts that society has made illegal or, at least, disapproves of" may be against public policy. ${ }^{211}$ There might be reason to rethink this rule, especially if relaxing it could help solve the orphan works problem. However, even if it is acceptable that the user can be relieved of her duty to seek permission before using a work by paying a fee to someone other than the copyright owner, it is not self evident that the collecting society should be the preferable payee. If allowing users to insure themselves against the risks arising from unauthorized use of orphan works is a good solution, then there is no reason to designate a collecting society as

211. See Truck Ins. Exch. v. Ashland Oil, Inc., 951 F.2d 787, 790 (7th Cir. 1992). This should be distinguished from Errors and Omissions insurance policies that may cover the risk of non-deliberate infringement claims. See also Howard P. Knopf, Copyright Collectivity in the Canadian Academic Community: An Alternative to the Status Quo?, 14 I.P.J. 109, 122 (1999) (noting that the legislation was needed to allow responsible publishers to obtain libel insurance because contracts for indemnification of illegal acts, such as contracts for libel insurance, were unenforceable under the common law). 
the sole insurer. It would be better to have a competitive insurance market instead.

\section{THE POLITICAL ECONOMY OF THE COPYRIGHT DOGMA}

A discussion of solutions to the orphan works problem will not be complete before addressing why has it been so challenging to find an acceptable and workable solution to this problem in the first place. The difficulty is puzzling because owners of orphan works are, by definition, absent from the debate about orphan works, and normally, when discussions about contemplated reforms do not involve those who might be directly affected by them, one could expect that reform would be easy. Specifically, one could expect that in a setting where users lobby for reform that would allow them to use orphan works, and owners of those works are absent, passing a pro-user reform (even overly pro-user) would be a breeze. Therefore, the fact that it has been difficult to find an acceptable solution, and that many of the proposed solutions involve serious impediments on using orphan works, suggest that the political economy of the orphan works problem is complicated, and that there is much at stake-not necessarily for the interests of orphan owners, but for the interests of those who speak on their behalf. This Section looks at some of these interests in order to understand who stands to win and lose from different solutions, and who has an interest in promoting the copyright dogma. This Section shows that besides some legitimate concerns, anti-competitive or opportunistic motivations drive many of the objections and the proposed solutions.

Answering the puzzle begins with the recognition that the interests of those who claim to speak on behalf of the orphans and the interests of the orphans themselves may not always be aligned. Evidently, when Amazon's counsel argued before Judge Chin that a copyright owner may sit back and do nothing, he was not defending the interests of the orphans or of any other copyright owner for that matter; ${ }^{212}$ he must have been more concerned about how Google Books might affect his client's online retail business. But even the interests of known copyright owners and their organizations may not be fully aligned with the interests of the owners of orphan works. Indeed, there are several ways in which promoting the copyright dogma benefits the interests of the known, commercial, or organized copyright owners' groups in ways that do not necessarily advance the interests of orphan owners. Some of their concerns are legitimate, while others are less so.

212. See Authors Guild v. Google, Inc., 770 F. Supp. 2d 666, 681 (S.D.N.Y. 2011). 
Known owners may be legitimately concerned about false positives. Many proposed solutions depend on defining conditions under which a work may be designated as "orphan." This creates a risk that courts would treat some works as orphans even when their owners are locatable. ${ }^{213}$ Although this concern is legitimate, eliminating the risk may increase the likelihood of false negatives, namely, works that should have been treated as orphans but are not. Indeed, this is what happened to the Copyright Office proposal from its 2006 Report, to the 2008 Bill, as more stringent requirements on users were added before a work could be treated as a "orphan." While these changes might have reduced the risk of false positives, they increased the risk of false negatives, and therefore might excessively deter the use of orphan works. ${ }^{214}$

Other objections to simple and workable solutions may be motivated by less legitimate concerns. Some copyright owners have nothing to gain from any change in the status quo, and therefore perceive any deviation from it as potentially harmful. Recall that relaxing the permission-first rule by recognizing a duty to make oneself locatable can benefit future users, the public in general, as well as present owners (by encouraging reuse and revival even if owners let their works become orphans). But relaxing the rule does not benefit all owners to the same degree, because owners of non-orphan works are those who, by definition, believe that the present value future uses is larger than the cost of making themselves locatable. Therefore, these owners are unlikely to benefit from change to the status quo of a strict permission-first rule, and might perceive any deviation from it as potentially harmful.

An additional motivation for objection could be termed as anticompetitive, while the last one can be called opportunistic. A strict permission-first fosters a "clearance culture" 215 that can function as a barrier to entry and protects large copyright owners from competition in several markets. Entities who own or administer large portfolios of works, such as big publishers, or the music and film "majors," have comparative advantage in making themselves locatable and maintaining ownership information

213. See Edward Hasbrouck, Facts and Fallacies of "Orphan Works," THE PRACTICAL Nomad Blog (Apr. 4, 2012, 12:02 PM), http://hasbrouck.org/blog/archives/001996.html.

214. See supra Part VII.

215. Patricia Aufderheide \& Peter Jaszi, Untold Stories: Creative CONSEQuences of THE Rights Clearance Culture For DOCUMENTARY Filmmakers 22 (2004), available at http://www.acsil.org/resources/rights-clearances-1/nps240.tmp.pdf (defining "clearance culture" in the context of documentary filmmaking as "the shared set of expectations that all rights must always be cleared-both imposed upon filmmakers and imposed by them on themselves and colleagues"). 
compared to small owners. A strict permission-first rule makes it more difficult and risky to use works other than those that these entities can license and therefore benefits them by making the licensing markets less competitive.

Many of these entities are also producers of content, and the clearance culture that the dogma fosters creates a barrier to entry in the markets for their produced content. While they may occasionally benefit from a less stringent a permission-first rule when reusing others' works, large producers might still find the copyright dogma worth defending because they can easily thrive in a clearance culture, whereas smaller producers and new entrants may find this culture very difficult to navigate. ${ }^{216}$

Another anti-competitive motivation is the concern that under some conditions orphan works could serve as substitutes for non-orphans. Consequently, reforms that may increase the supply of usable orphan works will erode the market power of the non-orphans. Indeed, objections of this kind were made explicit in debates in France. In its submission with respect to solutions to the orphan works problem, the French Centre Français d'exploitation du droit de Copie ("CFC"), a collecting society that licenses books and press reproduction rights, demanded that the use of orphan works would be permitted only if compensation is made to a collecting society, because (a) otherwise, orphan works freely accessible online would create "unfair competition" with works that are commercially available (presumably, the works of CFC members); and (b) permitting orphan works to be freely accessible online would devalue the content of commercially available works and encourage users to demand free access to all works. ${ }^{217}$ In other words,

216. Jeremy Williams, Who is concerned about broader access to orphans and why?, Berkeley Orphan Works Symposium, audio available at http://media.law.berkeley.edu/qtmedia/ BCLT/bclt_20120412-symposium/day1/Williams.m4a Jeremy Williams from Warner Brothers Entertainment, Inc. described at the symposium how unlike small producers, Warner's large legal department is capable of clearing rights).

217. Bernard Lang, L'exploitation des oeuvres orphelines dans les secteurs de l'écrit et de l'image fixe [Annex to the CSPLA Report], 19 (Mar. 17, 2008), http://www.datcha.net/orphan/oeuvres-orphelines-BLang.pdf (citing Les oeuvres Orphelines dans le Secteur de l'Écrit, Groupe de travail CFC, note d'étape, 2, 2 octobre 2007, available at http://bat8.inria.fr/ lang/orphan/documents/france/CFC-NOTE-DETAPE-2007.10.02.pdf). Interestingly, in the recent eBooks antitrust litigation, the defendant publishers made similar arguments. One of their justifications for agreeing with Apple on an "agency" pricing model was the concern that the low prices that Amazon charged for e-books under the previous "retail" model would devalue hardcover books, reduce consumers' willingness to pay higher prices for hardcover books and force publisher to lower the retail price of those books. See Jonathan M. Jacobson \& Kimberley A. Piro, Storm over E-books Waters, in COMPETITION LAW JOURNAL: CONCURRENCES 14, 14-15 (2012), available at http://ssrn.com/abstract $=2140778$. 
legally usable orphan works will increase the supply of usable works, which will force down the prices set by CFC or its members.

The third motivation can be termed as merely opportunistic. The motivation here is not a concern about harm (whether cognizable or not) but about seizing an opportunity to profit: realizing that there is value in the use of orphan works, the objection is aimed at ensuring that this value would be captured by the objector and not by others.

The entities that have the clearest interest in promoting the copyright dogma are collecting societies, who can bring the anti-competitive and the opportunistic motivations to perfection. Unlike their members, some of which may sometimes find themselves on the user side, collecting societies neither produce content nor distribute it. Their business consists merely of licensing content already produced and delivered by others, and they are driven by a single objective: to maximize the license fees that they collect. For collecting societies any market failure, whether real or perceived, presents a business opportunity in the form of a new area of activity that they will be prepared to collect money for. ${ }^{218}$ Consequently, they view any reform that would facilitate transactions in a competitive market as a lost opportunity to collectively license this activity, and any proposal to exempt some activities that they are happy to license as an existential threat. ${ }^{219}$ As organizations driven by a single purpose, they do not need to trade off the inefficiencies that the rules that they promote create, and even when those

218. David Vaver, Commentary, in Proceedings of THE Colloquium on THE COLLECTIVE ADMINISTRATION OF COPYRIGHT 161, 166-68 (1994) (on file with author).

219. For example, Access Copyright, a Canadian collecting society representing publishers and some authors has lobbied forcefully against any expansion of Canada's fair dealing provision, and in particular, against the explicit inclusion of "education" as a recognized purpose. See ACCESS COPYRIGHT, ANNUAL REPORT 20117 (2012), http://www.accesscopyright.ca/media/22585/2011_annual_report.pdf. According to a 2007 report, commissioned by Access Copyright, and written by Prof. Martin Friedland, more than $75 \%$ of Access Copyright's income came from licensing the educational sector (K-12 and post-secondary), in contrast to the U.S.-based Copyright Clearance Center, whose income from the education sector amounted to only $12 \%$ of its income and has not operated in the K-12 area at all. See MARTin Friedland L., RePORT tO ACCESs Copyright On DiSTRIBUTION OF ROYALTIES 19 (2007), available at http://www.accesscopyright.ca/media/ 8359/access_copyright_report_-_ffebruary_15_2007.pdf. Remarkably, despite the fact that the population in Canada is about one-tenth of the U.S. population, Access Copyright collected more money from the education sector than the CCC did. According to Friedland, in 2006 CCC collected approximately $\$ 19$ million from the education sector. $I d$. at 24 . Access Copyright total revenue in 2006 was $\mathrm{C} \$ 34.2$ million, meaning that it collected approximately C\$27 million from the education sector (or \$23.6 million). See ACCESS COPYRIGHT, ANNUAL REPORT 200710 (on file with the author). It is, therefore, clear why Access Copyright lobbied forcefully to prevent the explicit recognition of "education" in the fair dealing provision. 
inefficiencies affect their members, the additional profit arising from collecting societies' ability to collect monopolistic fees for the use of their members' works may compensate the members for the losses that those inefficiencies create.

Naturally, collecting societies are eager to become the guardians of orphan works. The ability to charge users a fee for the use of orphan works through an ECL mechanism allows them: (a) to control the supply of orphan works and ensure that they do not compete with the works of their members (the anti-competitive motivation); and (b) to profit from, and appropriate the value of, the use of the works of others (the opportunistic motivation). While the benefits of ECL to the collecting society and its members may be obvious, it is less obvious that installing a monopoly of non-orphans as a custodian and gatekeeper of orphans benefits users and the public at large. The problem is that the stakes for the collecting societies (and their members) and users are asymmetric. Under competitive solutions, users can only expect to earn normal returns, whereas under ECL the collecting society and its members can earn supra-competitive returns. The copyright owners, because they can gain more, can rationally spend more resources on lobbying for a monopolistic solution than users would spend on lobbying for competitive solutions. ${ }^{220}$ Moreover, since the owners of orphan works are by definition not members of collecting societies, it far from clear why a collecting society would be entrusted with their guardianship. Therefore, to promote themselves as the only acceptable solution, collecting societies (or owners seeking to establish new ones) need to promote the notions that permission-first is the unquestionable tenet of copyright, that the orphan works problem is an insurmountable one, and that they are the only ones who can come to the rescue. In other words, to sell ECL, its proponents need to frame the problem in terms that define ECL as the only possible solution.

Therefore, the move to ECL requires not only promoting permissionfirst as fundamental tenet of copyright, but it also requires some doctrinal innovation that transforms copyright law into a copyright dogma. What distinguishes the copyright dogma from copyright law is that the dogma abandons the notion of copyright as a set of bilateral and correlative rights and duties of owners and users and defines copyright solely by the prohibitions it imposes on users. The dogma removes copyright law from the

220. Cf. Patry \& Posner, supra note 32, at 1645. Patry and Posner identify these asymmetric stakes as a general problem in copyright. Collecting societies aggravate the problem because they generate industry-wide monopoly rents above the rents that an individual copyright owner could get by virtue of the copyright. 
realm of private law and thus removes the constraints that the bipolar relationships between owners and users impose on "the very scope and structure of both the action and the entitlement."221 As Balganesh explains:

The bipolarity of private law entitlements ... ensures that a plaintiff will seek relief only against a specific defendant (rather than the state or society), that a defendant will be ordered to compensate a specific plaintiff (rather than the collective), and perhaps most importantly, that the relief sought and recovery obtained will be determined entirely by the parties' actions rather than by any external determinants. ${ }^{222}$

The dogma serves collecting societies and their members because it transforms the wrong of copyright infringement from copying that harms the copyright owner to copying that is harmful per se; from copying without the permission of the copyright owner, to copying without permission of $a$ copyright owner; and then from copying without paying the owner, to copying without paying a copyright owner, or better yet, copying without paying an organization of copyright owners. This kind of dogmatic innovation allows collecting societies to transform copyright law into an apparatus for monetizing sin, which brings us back to the sale of indulgences by the Catholic Church.

In the provocative book Sacred Trust: The Medieval Church as an Economic Firm, Robert Ekelund and his coauthors analyze the medieval Catholic Church as a corporation that promoted and offered a "product" that many consumers felt they had to have: the salvation of their immortal souls. ${ }^{223}$ The Catholic Church was not the only religion offering this product, and one of its methods to monopolize this market was doctrinal innovation. The invention of the purgatory - a temporary state between heaven and hellwas a central element in this doctrinal innovation. ${ }^{224}$ Ekelund et al. describe the doctrine as follows:

The Church held that sins had to be paid for either in this world or the next. Payment was proportioned to guilt. Grievous offenses (i.e., mortal sins) condemned one to hell if the offender died unrepentant. Purgatory was of no consequence in such cases. However, sinners who repented and received absolution from a priest retained the opportunity to enter heaven, provided they did

221. Balganesh, supra note 25 , at 1667.

222. Id. at $1667-68$.

223. Robert B. EKELUnd ET AL., SACRED trust: THE MEDIEVAl CHURCH AS AN ECONOMIC FIRM 152 (1996).

224. Id. at 153 . 
penance. Before purgatory came to be official doctrine, sins could be atoned on earth only by good works, that is, payment rendered directly within one's earthly lifetime. The invention of purgatory essentially introduced a means of "deferred payment," which not only allowed atonement to be postponed beyond this life, but also allowed third parties to make payments on behalf of the deceased. $^{225}$

Initially, sins could be atoned only by good works, but over time, further innovation occurred, whereby monetary payment, obtained by the sale of indulgences, was accepted in lieu of good works. ${ }^{226}$ Assuming that with some exceptions most potential believers have some affinity to commit venial sins, these innovations reduced the price of sin, which made the product of the Catholic Church more attractive than that of its competitors. ${ }^{227}$ Ekelund et al. ask, "[B] ut why would the Church introduce a doctrinal innovation that encouraged sin?", and offer an economic answer: "The Church wanted to increase its membership and prevent existing members from defecting to alternative religions that offered assurances of salvation at a lower price. In other words, at least in part, purgatory is a market response to doctrinal competition." 228

Essentially, through doctrinal innovation the Church was able to monetize sin. Not only it was able to outcompete other religions who charged a higher price for sin, the business of monetizing sin through the sale of indulgences proved to be highly lucrative. The doctrine further ensured that the authority over the sale of indulgences, and the opportunity to profit, would be concentrated in the hands of the Vatican. ${ }^{229}$

Discussing the merit of medieval Catholic dogma is certainly beyond the scope of this Article, but the elements of monetizing sin through the sale of indulgences is common to ECL, the Canadian regime, and similar proposals. Promoting the idea that reusing orphan works is inherently sinful, and that to save their souls from the copyright hell of strict liability users should purchase indulgences from the Copyright Church, may enrich the institutions of the Copyright Church. Meanwhile, it preserves the flawed notion that any use of a work without permission is wrongful, hinders the emergence of competing visions of copyright law, and suppresses the resurrection of the orphans.

225. Id. at 154-55.

226. Id. at $155,157$.

227. Id. at 156 .

228. Id. at 157.

229. Id. at $157-58$. 


\section{CONCLUSION}

In general, copyright requires users to seek permission before the copy protected works. Generally, the permission-first rule makes sense because it supports copyright's market orientation, but when permission-first leads to a market failure copyright law should, and often does, deviate from it.

The orphan works problem is just one instance of a case in which adhering to a strict permission-first rule leads to a market failure, but solving this market failure does not require any grand solution. No rewriting of copyright's basic tenets is necessary, and there is no need to create new monopolies, bureaucracies, or a combination of both. Solving the orphan works problem requires recognizing its causes. The problem arises not only because users find it prohibitively costly to locate owners, but because under a strict permission-first rule owners, who do not internalize the full social cost of forgone uses, face suboptimal incentives to maintain themselves locatable. Yet copyright owners are generally the least-cost avoiders of this problem and solving the problem requires adjusting the users' duty to seek permission with the owners' duty to maintain ownership information available. This is not a radical proposal: it is elementary. Imposing a duty to reduce avoidable costs on the party who is best suited to avoid them is prevalent throughout the law. If lawmakers feel impeded from applying this principle in copyright, it is only because they have been blinded by the indoctrination of the copyright dogma.

If owners do not presently face sufficient incentives to maintain themselves locatable, limiting the full array of remedies for failure to remain locatable will encourage them to remain locatable. Remedy tweaking will shift some of the risk of using orphan works from users-who currently bear it entirely - to owners. Creating incentives for keeping ownership information up to date will reduce the scope of the orphan works problem, without resorting to solutions that undermine copyright law's market orientation, and require costly procedures and unnecessary bureaucracies.

The low cost of making themselves available is key, and we should start thinking seriously about copyright registration. We do not have to reintroduce mandatory registration, but we do need to provide incentives to keep ownership information up to date and accessible, be it on a government-run registry or otherwise. ${ }^{230}$ Consequences for failing to

230. See Molly Shaffer Van Houwelling, Author Autonomy and Atomism in Copyright Law, 96 VA. L. REV. 549, 630-32 (2010) (discussing various mechanisms that can facilitate recordation and access to ownership information). 
maintain copyright ownership information available will create demand for low-cost ownership data solutions. ${ }^{231}$

Obviously, talking about registration immediately brings up the specter of violating the Berne Convention and its prohibition on formalities. ${ }^{232}$ This Article will leave the discussion about remedy tweaking amounts to a prohibited "formality" for another day, but whether this is the case or not, Berne should not be an excuse for paralysis and inaction. The Berne Convention bans formalities principally because when it was negotiated, complying with the registration requirements that many countries imposed was overly onerous. ${ }^{233}$ But registration does not need to be onerous, and much can be done in ways that are consistent with Berne. ${ }^{234}$ We will never know what Berne exactly prescribes unless we test it. This Convention should not become the New Dogma, and Berne should not become the New Rome of the Copyright Church. If the Berne Convention does not allow us to do anything, then it should be reformed or abandoned.

The fact that we have created a system of ownership that does not require any record of ownership is one of the most serious copyright policy failures of our time. Copyright lasts longer than ever, it covers more works than ever, applies to more uses than ever, and the ways of using and reusing works are more complex and varied than ever. At the same time, there is no record of who owns what, at least not a universally accessible, usable, and reliable record. We want markets to function in this reality. They cannot. Developed markets cannot exist without a clear sense of who owns what, and markets for creative works are no exception. We would not expect real estate markets to function efficiently without land registration, and functioning securities markets without reliable records of securities' ownership are hard to fathom. Why would we think that copyright is different? This ownership mess is not going to disappear spontaneously anytime soon, and it is not an American or Canadian or European problem.

231. Patry \& Posner, supra note 32 , at 1651.

232. See Berne Convention for the Protection of Literary and Artistic Works, Paris Act, July 24, 1971, 25 U.S.T. 1341, 828 U.N.T.S. 221, Art. 5(2) ("The enjoyment and the exercise of these rights shall not be subject to any formality ....”); see generally Stef Van Gompel, Formalities in the Digital Era: An Obstacle or Opportunity?, in GLOBAL COPYRIGHT: THREE Hundred Years Since the Statute of AnNe, From 1709 to CyberspaCe 395, 396 (L. Bently, U. Suthersanen \& P. Torremans eds., 2010); Christopher Sprigman, Reform(aliz)ing Copyright, 57 STAN. L. REV. 485, 541 (2004).

233. See Van Gompel, supra note 232, at 418; Sprigman, supra note 232, at 544.

234. See Sprigman, supra note 232, at 554-68 (discussing Berne-compliant "new-style" formalities). 
It is a global problem that affects every reading, watching, or listening person around the world.

As long as copyright law adheres to a strict permission-first rule and ignores owners' capacity to avoid the problem, the orphan works problem will appear to be a grand problem that requires grand solutions. But the political economy of copyright suggests that some grand solutions, such as radically reducing copyright terms, or reintroducing mandatory registration and renewal fees, are presently unrealistic, whereas more realistic grand solutions such as ECL may provide some immediate short-term fix, but might create persistent long-term side effects.

Copyright law was born out of revolt against the monopoly of the Stationers' Company over the book trade, and the role that it played, alongside the Crown and the Cross, in controlling the press and suppressing the free dissemination of knowledge, which the invention of print facilitated. ${ }^{235}$ We should keep this point in mind when we consider solutions to the orphan works problem, and we should be reluctant to adopt solutions that bring back a new version of the Stationers' Company, and entrust monopolies and bureaucracies as guardians of orphan works and gatekeepers of knowledge, as society moves from print to digital.

235. See sources cited supra note 8 . 